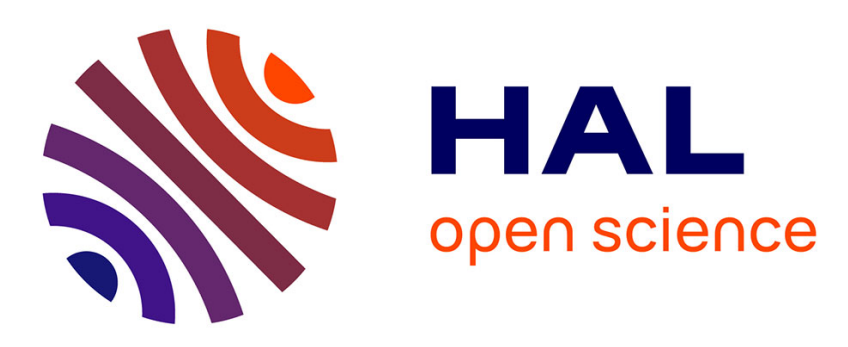

\title{
Estimated Minimum Lifespan of the Jezero Fluvial Delta (Mars)
}

Francesco Salese, Maarten Kleinhans, Nicolas Mangold, Véronique Ansan, William Mcmahon, Tjalling de Haas, Gilles Dromart

\section{- To cite this version:}

Francesco Salese, Maarten Kleinhans, Nicolas Mangold, Véronique Ansan, William Mcmahon, et al.. Estimated Minimum Lifespan of the Jezero Fluvial Delta (Mars). Astrobiology, 2020, 20 (8), pp.977993. 10.1089/ast.2020.2228 . hal-02933206

\section{HAL Id: hal-02933206 https://hal.science/hal-02933206}

Submitted on 8 Sep 2020

HAL is a multi-disciplinary open access archive for the deposit and dissemination of scientific research documents, whether they are published or not. The documents may come from teaching and research institutions in France or abroad, or from public or private research centers.
L'archive ouverte pluridisciplinaire HAL, est destinée au dépôt et à la diffusion de documents scientifiques de niveau recherche, publiés ou non, émanant des établissements d'enseignement et de recherche français ou étrangers, des laboratoires publics ou privés. 


\title{
Estimated Minimum Lifespan of the Jezero Fluvial Delta (Mars)
}

Francesco Salese ${ }^{1,2}$, Maarten G. Kleinhans ${ }^{1}$, Nicolas Mangold ${ }^{3}$, Veronique Ansan ${ }^{3}$, William McMahon ${ }^{1}$, Tjalling de Haas $^{1}$, Gilles Dromart ${ }^{4}$

${ }^{1}$ Faculty of Geosciences, Utrecht University, Princetonlaan 8a, 3584 CB, Utrecht, The Netherlands.
${ }^{2}$ International Research School of Planetary Sciences, Università Gabriele D’Annunzio, Viale Pindaro 42, Pescara, Italy.
${ }^{3}$ Laboratoire de Planétologie et de Géodynamique de Nantes, UMR6112, CNRS/Nantes University, Nantes, France.
${ }^{4}$ Laboratoire de Geologié de Lyon, Université de Lyon, 69364 Lyon, France.
*e-mail: f.salese@uu.nl

Key words

Jezero fan-delta - Lake - Mars - Landing Site - Fluvial activity - Neretva Vallis

\begin{abstract}
The paleo-lake floor at the edge of the Jezero delta has been selected as the NASA 2020 rover landing site. In this paper we demonstrate the sequences of lake filling and delta formation, and constrain the minimum lifespan of the Jezero paleo-lake from sedimentological and hydrological analyses. Utilizing imagery provided by the High Resolution Imaging Science Experiment (NASA Mars Reconnaissance Orbiter) and High Resolution Stereo Camera (ESA Mars Express), two main phases of delta evolution can be recognized. 1) Basin infilling before the breaching of the Jezero rim; and 2) the delta formation itself. Our results suggest delta formation occurred over a 90 - 550 year period of hydrological activity. Breaching of the Jezero rim occurred in at least three distinct episodes, which spanned a far longer time-period than overall delta formation. This evolutionary history implies the Jezero-lake floor would have been a haven for fine-grained sediment accumulation, and hosted an active environment of significant astrobiological importance.
\end{abstract}

\section{Introduction}

Remnants of ancient deltas provide a critical record of ancient surface flow on Mars. Interpretations of these sedimentary archives are of fundamental importance for quantifying the hydrological history of the planet. A range of delta-types have so far been recognized (e.g., Di Achille and Hynek [2010]; Hauber et al. [2013]; Salese et al. [2019]), including simple stepped deltas [Irwin III et al., 2005; Di Achille et al., 2006; Weitz et al., 2006; Kraal et al., 2008; Hauber et al., 2013; Salese et al., 2019], complex and lobate deltas [Pondrelli et al., 2008; Mangold et al., 2012; Hauber et al., 2013; Salese et al., 2016] in addition to Gilbert-type deltas [Ori et al., 2000; Di Achille et al., 2007; Hauber et al., 2013; Salese et al., 2019]. Whereas stepped deltas are readily explained by a single outflow event [Kraal et al., 2008; de Villiers et al., 2013], many studied systems are far more complex because they have much greater catchment areas and often relate to breached craters. The Jezero crater delta, along with Moa Valles-Liberta [Salese et al., 2016], Eberswalde crater [Malin and Edgett, 2001; Pondrelli et al., 2008; Mangold et al., 2012] and Sabrina and Hypanis [Adler et al., 2018], are among the few Martian deltas with evident stratigraphy, avulsing channels and multilobate depositional patterns. Previous studies have yielded conflicting estimates of the time-scale of evolution within the Jezero delta, with the total duration of hydrological activity ranging from mere decades to upwards of millions of years [Fassett and Head, 2005; Ehlmann et al., 2008; Schon et al., 2012; Goudge et al., 2015]. Notably, it remains unclear whether (or not) delta formation occurred during extended epochs of clement climatic conditions (favorable for life), or during punctuated intervals of allogenically forced sedimentary events (e.g., regional impacts, volcanism, or tectonics) (e.g. Brakenridge et al. [1985]; Hauber et al. [2013]; Halevy and Head [2014]). This latter hypothesis would imply that lake conditions may not have been dissimilar from the present day, thus likely prohibitive for life. 
The aims of this paper are: a) to re-examine the delta-forming discharge from the Neretva Vallis; b) to consider the active lake's water supply and loss mechanics; and c) to determine the geologic timescale of delta formation.

Utilizing high-resolution digital elevation models we estimate the systems hydrological potential, and propose different scenarios of evolution with varied key sediment transport parameters (e.g., grain size). Sediment transport predictions are intricately linked to estimates of grain size, channel depth and gradients, such that minor differences in input conditions may result in sediment budget outputs orders of magnitude apart (perhaps explaining the contradictory estimates of Jezero Crater evolution predicted by previous researchers [Fassett and Head, 2005; Ehlmann et al., 2008; Schon et al., 2012; Goudge et al., 2015] (Figure 1). Despite imbedded (and unavoidable) uncertainties, physics-based predictors (used in this work, rather than empirically-based estimates) provide the most robust flow and transport rates available. Empirically-derived hydrological estimates which assume fixed sediment concentrations (e.g. Moore et al. [2003]; Irwin et al. [2004]; Mangold et al. [2012]; Irwin et al. [2015]) may yield incorrect estimates of system duration because: 1) considering the power law-dependence of sediment flux on flow shear stress, a simplistic assumption can be wrong by several orders of magnitude, while physics-based methods are always within two orders of magnitude even with a large uncertainty of original grain size; 2) sediment concentration values applied by previous authors are relatively high, and imply unrealistic hyperconcentrated flows (considering the lowgradient slopes and probable hinterland conditions). Morphometry, valley topography, discharge rates of channels and their stratigraphic relationships with lithological units of origins other than the fluvial and lacustrine are investigated in a companion paper (Mangold et al. companion paper).

\subsection{Jezero crater context}

Jezero is a $50-\mathrm{km}$-diameter crater with a volume of $463 \mathrm{~km}^{3}$. It is a shallow impact basin with a major channel system cutting its western rim. The crater contains a large irregular fan deposit with a minor channel entering from the north [Fassett and Head, 2005] (Figure 2a). We model the contribution to the crater infilling and delta formation of the western main valley and we also analyse the breach evolution at the eastern side of the crater. The northern valley does not contain evidence of fan deposition and is overall poorly developed. The crater is breached on the eastern side where there is a connected erosive channel network (Figure 1). The maximum elevation inside the crater basin which water may have reached is $-2243 \mathrm{~m}$ (Figure 2 - Profile R-S). Both the elevation of the delta front and the bottom of the breach is $-2410 \mathrm{~m}$ (Figure 2 - Profiles O-Q and R-S). All parameters (delta surface, volume gradient, eroded sediment valley volume, crater rim diameter, observed depth below rim peak, volume of the breach) were accurately delineated through our Digital Elevation Models (DEMs; see Methods section). The observed depth below the rim peak in this case matches with highest breaching point at $-2243 \mathrm{~m}$ below the Mars datum. Nevertheless, erosion of particular deltaic subenvironments (e.g., offshore delta toe-sets) have been eroded, with this missing geomorphic evidence potentially leading to underestimates of the total active duration for the Jezero system.

\section{Methods}

\subsection{General approach}

We use established hydrological and sediment transport predictors that are well-tested for terrestrial conditions and corrected for Martian gravity [Kleinhans [2005]]. The principle of these formative time-scale is that flows require a certain minimum duration to work (i.e., remove, transport or deposit a known sediment volume), and must involve a certain volume of water that is sometimes constrained in non-overflowing lakes [Kleinhans, 2005; Roda et al., 2014]. While flow and sediment transport predictors undoubtedly simplify 
reality, the timescales of morphology development are rather well-constrained by this methodology. We use these predictors to estimate the duration of the Jezero fluvial system and we further test it on well constrained terrestrial (Holocene) cases, including the Wax Lake Delta and Lake Constance, to corroborate general validity (previously assessed by Duller et al. [2015]). In order to obtain a range of possible predictions, we simulated a number of conditions for the most uncertain and sensitive variables (i.e., grain size and channel dimensions). Channel width and slope can be derived from visible images and digital elevation model (DEM) both for terrestrial (Wax Lake Delta and Lake Constance) and Martian (Jezero delta) examples. Channel depth can be directly measured on Earth and estimated on Mars using DEMs (with indications for original water depth ranging between preserved terrace height and bankfull flow conditions). Flow velocity was estimated using a friction law and a measured depth from altimetry data. Channel width, depth and slope were carefully measured using HiRISE DEM's for the Jezero delta (in addition to the Jezero breach because overor under-estimating depth not only affects derived discharge but also, indirectly, the velocity (through the roughness equation, see Kleinhans, [2005]). Sediment flux is calculated using two methods: one assuming a bedload-dominated transport (with mostly rolling and saltating particles and limited energy), and another assuming a suspended load-dominated event (non-cohesive granular material). The sediment mobility, which depends on flow and sediment properties, is used to determine which of the two transport modes is most valid. In such a system, suspended/bedload transport ratio is far larger than one, so classic suspensiondominated sediment transport capacity predictors are employed corrected for Martian conditions Kleinhans [2005]. Models are based on steady and uniform flows equal to the water surface slope and channel bed surface slope.

In this paper we assume, based on morphological evidence (terraces), a constant (5 metre deep) bankfull discharge. While it is likely that some form of hydrograph is more representative of original flow conditions, the combination of the magnitude-frequency relation of flow and the nonlinearity of sediment transport renders the average sediment transport rate closer to the bankfull discharge than high-peak variance. This is due to the fact that the most extreme discharges (while transporting disproportionally more sediment) are quite rare, while the lowest discharges (while perhaps much more common than the bankfull condition) induce little sediment transport. These assumptions are in agreement with observations that the resulting channel dimensions' scale well to bankfull discharge as a measure for the channel forming discharge of fluvial channels [Leopold et al., 1964].

We assume transport of one sediment size whereas in reality there would have been a mixture. In particular, the Jezero delta is likely composed of a range of grain sizes, suggested by the interior of the delta, which shows variations between the supposed point bar, likely sand facies and the inverted channels above. We modelled scenarios for a range of grain sizes to bracket possible conditions (Table 1). Furthermore, many terrestrial deltas develop floodplains and toesets from fine material transported as washload, which is the part of the suspended load that is composed of particle sizes smaller than those found in appreciable quantities in the bed material. It is in near-permanent suspension and, therefore, is transported through the stream without deposition. This washload cannot be determined from the capacity predictors because it is supply-limited from the hinterland rather than capacity-limited by flow. Furthermore, using the water balance we calculate discharge for basin infilling, but we cannot measure the evaporation or pan-evaporation rate due to the lack of paleoclimate parameters on Mars, or the rate of outflow above $-2243 \mathrm{~m}$ elevation due to the subsequent erosion of the crater rim.

\subsection{Data}

Data used in this study include all types of visible images acquired for this basin, especially High Resolution Stereo Camera images (HRSC, 12,5 m/pixel, Neukum et al. [2004]), Context images (CTX, 6 m/pixel, Malin et al. [2007]) and High Resolution Imaging Science Experiment images (HiRISE, $25 \mathrm{~cm} / \mathrm{pixel}$, McEwen et al. [2007]). Mosaics of these datasets have been assembled in a Geographic Information System (GIS) enabling 
morphometric measurements. The basin topography has been obtained from CTX and HiRISE Digital Elevation Models (DEMs), Neretva Vallis values were estimated throughout HiRISE DEMs (1 m/pixel resolution).

\subsection{Case Study}

We calculated minimum formation times for the Jezero deltas and basin infilling as a function of channel width, depth, and grain size. Formation times were based on predicted water and sediment discharges in comparison to observed lake volume and erosion and deposition volumes. In particular, for the Jezero delta (Mars) we used channel depth of 5 meters and two different values for channel width: 190m and 50m. The first value is measured using the HiRISE DEM and the second obtained from Fassett and Head [2005]. This second width value is merely applied to demonstrate the sensitivity of the model to width parameter (and in doing so allows application of a more conservative estimate of channel width). The only absolute value of Martian grain size was obtained from alluvial fan material inside Gale Crater [Williams et al., 2013 ]. Evidently inappropriate for application at Jezero, in this study we present a range of different D50 values, from fine sand $(0.25 \mathrm{~mm})$ to pebble $(20 \mathrm{~mm})$. For the D90 value we used the relation $5^{*} \mathrm{D} 50$ [Kleinhans et al., 2010]. Sediment and water discharges were derived from the river morphometric parameters using an online supplemental spreadsheet [Kleinhans, 2005] based on the equations listed in Kleinhans [2005]. We then discussed and estimated the longevity of deposition as a function of the inlet (Neretva Vallis) and outlet balance, making comparisons to prior works [Fassett and Head, 2005; Ehlmann et al., 2008; Schon et al., 2012; Goudge et al., 2015].

With respect to previous Martian analogue studies applying the same model (e.g. Kleinhans [2005], Kleinhans et al. [2010]), our approach is more representative of actual deltaic deposition as we used CTX and HiRISE DEMs to measure width, depth, bedload transport, sediment slope failure of the Neretva Vallis and terrestrial analogues unaffected by tidal processes. This allows us to use more accurate input parameters than those applied in previous studies (e.g. Kleinhans [2005]; Kleinhans et al. [2010]), particularly for river depth, which is one of the most important parameters which affects the sediment transport process and is difficult to constrain on the basis of erosional channel topography alone [Marra et al., 2014]. High-resolution topographic data also enable more accurate geological and hydrological analyses, yielding predictions closer to those of typical rivers on Earth.

\subsection{Model Validation}

Model validation was already presented in Kleinhans [2005] for terrestrial and experimental systems including the Mackenzie and Rhine (NL) [Berendsen and Stouthamer, 2000; Hill et al., 2001]. The methodology and the equation introduced by Kleinhans [2005] was then implemented by Hoke et al. [2011] to assess timescales of formation for seven of the largest ancient Martian valley networks. The model was also used on Mars by Mangold et al. [2012] and Adeli et al. [2016], with an aim of understanding the timescale of evolution of the Eberswalde delta and the fluvial system in Terra Cimmeria respectively. de Villiers et al. [2013] tested the method directly for experimental crater lake deltas and Marra et al. [2014] showed it was additionally applicable to erosive experimental systems, and was further supported by a uniquely well-constrained erosional valley case on Mars: the Aram Chaos side valley to Ares Valles [Roda et al., 2014]. More recently, the above mentioned model used was applied to reconstruct the timescale of formation of the several Martian delta [Kleinhans, 2005; Kleinhans et al., 2010] and has already been validated on Earth by Duller et al. [2015], which applied it to reconstruct the timescales of the 1918 catastrophically formed fan in southern Iceland [Duller et al., 2008; Duller et al., 2014]. The real known duration of this event was 6-10 hours and the timescale predicted by their modelling is between 2 and 17 hours. Further, to strengthen their test they modelled several hypothetical Martian scenarios applied on the Iceland fan to illustrate potential limitations of using the final topography to estimate flow dimensions and 
Accepted paper in Astrobiology - Vol. 8 (2020)

using a typical value of grain size distribution recorded from Mars missions (as we did in this work). The resulting fan formation timescale was of 0.1 to $40 \mathrm{~h}$ (sand system) and 25 to $700 \mathrm{~h}$ (gravel system), within two orders of magnitude of the real timescale. If sedimentary information is available and used in conjunction with traditional topographic analyses, then the uncertainty in calculating fan formation and hydrologic timescales both on Earth and Mars can be greatly reduced.

As a further independent test of the method we modelled two recent river-dominated, terrestrial fan deltas for which all the input data are available (including precise start dates of delta formation): the Wax Lake delta (Louisiana, USA) and the Lake Constance delta (Austria). Input parameters, such as delta bathymetry, channel width and depth, mouth discharge, are all available from existing literature [Muller, 1966; Roberts et al., 1997; Roberts et al., 2003; Wellner et al., 2005; Shaw and Mohrig, 2014; Wessels et al., 2015a; Wessels et al., 2015b; Wessels et al., 2016]. The Wax Lake Delta is located in an open but sheltered basin with a microtidal range, whereas the New Rhine Delta is located in a closed basin (lake).

\section{Terrestrial delta modelling}

\subsection{Wax Lake delta}

\subsubsection{Sedimentological backgorund}

The 25-km-long man-made Wax Lake Outlet was completed in October 1941 [Roberts et al., 2003] and provides the opportunity to model a delta formed by a well-developed river with a precisely known initiation date. Wax Lake Outlet extends south from Six Mile Lake, across the Teche ridge, into Atchafalaya Bay. Original bottom depth was $\sim 13.7 \mathrm{~m}$ below mean sea level and the width was less than $12.2 \mathrm{~m}$ [Latimer and Schweizer, 1951]. The Wax Lake Delta (WLD), at its mouth, is a classic river-dominated delta [Wellner et al., 2005; Falcini and Jerolmack, 2010; Edmonds et al., 2011] and its form is negligibly affected by the small mean tidal range $(0.4 \mathrm{~m})$ and wave climate $(0.5 \mathrm{~m}$ maximum monthly wave height; Syvitski [2005]). A delta top slope of 0.0085 was measured from detailed bathymetric reports (Shaw et al. [2016]).

Researchers have monitored the WLD sedimentation since Morgan et al. [1953] and Morgan and Larimore [1957]. Roberts et al. [1980] suggest that by the late 1950s accommodation space within the Atchafalaya Basin was rapidly decreasing. The amount of sand-sized sediment reaching the bay consequently increased. Prior to 1960, the majority of sediment reaching Atchafalaya Bay was comprised silt-sized (or finer) grains, with most of this material bypassing the bay and depositing seaward of the Point au Fer Shell reef [Cratsley, 1975]. After 1960, sand-prone, subaqueous bayhead deltas formed at the mouths of the Lower Atchafalaya River and Wax Lake Outlet [Roberts et al., 1980].

The WLD, according to Cratsley [1975], experienced three different phases of sedimentation: (1) deposition of prodelta clays and silty clays from the middle of the 19th century to about 1952; (2) the initiation of coarser-grained deposition around 1952 (mostly silts), and the development of a lobate form between 19521962 (reported in Shlemon [1975] as well); and (3) introduction of bedload sands in the early 1970s. Cratsley [1975] also showed that thin silt and sand layers were found in the subaqueous delta and that the bulk of the sediments were fine grained and not sand rich.

Deposition between 1962-1972, and the high flood years of 1973-75, which stand out as a period of abnormally high sediment flux, changed bay framework significantly, with the WLD becoming subaerial. Mean discharge and total sediment discharge measured at Simmesport for the years 1951-1989 are summarized in Roberts et al. [2003]. Majersky et al. [1997] shows estimates of delta growth based on a terrain model using both bathymetry and land elevation data collected by the US Army Corps of Engineers. Between 1989 and 1994, the Wax Lake delta developed at a rate of $3.0 \mathrm{~km}^{2} \mathrm{y}^{-1}$ [Majersky et al., 1997]. These 
Accepted paper in Astrobiology - Vol. 8 (2020)

values clearly show the rapidly expanding nature of this delta and compare favourably with delta growth predicted earlier by Wells et al. [1982] from a genetic growth analysis based on the historic behaviour of subdeltas in the modern Mississippi delta, indicating that conditions of flow and sediment transport are within the expected range for this environment.

\subsubsection{Modelling}

The sediment timescales and delta formation were calculated for conditions shown within the spreadsheet in the supplementary material. We modelled sediment deposition (delta) between 1952 and 1989 based on variables listed by Roberts et al. [2003]. Grain size value (D50 and D90) are taken from Shaw and Mohrig [2014]. We divided the sedimentary history of this delta in two different periods: silt-dominated before 1961 and sand-dominated post 1961. We found that during the silt-dominated period the delta formed in two years (expected due to the higher mobility of silt). In the sand-dominated period it formed in almost thirteen years. For this case the calculated timescale is about two factors different from the true timescale (predicted using the spreadsheet: 15 years; reality: 37 years), which is acceptable given all the simplifications and the possible loss of sediment through wave reworking.

\subsection{New Rhine delta}

\subsubsection{Sedimentological background}

In 1900 (by a treaty between Austria and Switzerland) the position of the mouth of the Alpine Rhine (Alpenrhein), the upstream reach of the river Rhine, was shifted to a new artificial bed that flows into Fussach Bay (close to the town of Fussach in Austria) in the eastern part of Lake Constance [Muller, 1966]. Since then the Rhine began to build its present delta (the New Rhine delta) into Fussach Bay [Muller, 1966]. This provides the opportunity to model a delta formed by a well-developed river with an exactly known initiation date.

The Rhine flows into the Lake Constance at an elevation of $396 \mathrm{~m}$ above mean sea level. The average gradient between the source of the Vorderrhein and the mouth of the Rhine in Lake Constance (over a total length of about $170 \mathrm{~km}$ ) is 0.0115 . Lake Constance, with a volume of $49.4 \mathrm{~km}^{3}$ and a maximum depth of $252 \mathrm{~m}$ is the natural settling basin for the Rhine, which drains a total area of $6122 \mathrm{~km}^{2}$. Over $90 \%$ of the coarse sediment transported by the Rhine is deposited in Lake Constance and only a very small percentage leaves Lake Constance to be carried downstream to the North Sea [Muller, 1966] (making the lake an efficient sediment trap). Fine sediments compose the delta while the upstream river is gravel-dominated, and the New Rhine transports $85.5 \%$ of the suspended load and $1.2 \%$ of the bed load [Muller, 1966].

The average water flow discharge from 1931 to 1960 was $224 \mathrm{~m}^{3} / \mathrm{s}$; the average suspended load was 349.5 $\mathrm{cm}^{3} / \mathrm{m}^{3}$, or $454.1 \mathrm{~g} / \mathrm{m}^{3}$. Thus, the river supplies an average annual suspended load of $2.571 \mathrm{million} \mathrm{m}^{3}$, which is deposited into Lake Constance. The amount of bedload (pebbles transported by rolling that constitute less than $2 \%$ of the material transported in suspension [Muller, 1966]) is approximately $40,000 \mathrm{~m}^{3}$ per year, which is entirely contained within the delta. Seasonal deviations from the average are extreme; during the peak of the thaw period in the Alps, water flow can be ten times greater and the amount of suspended load can increase by more than twenty times. Through extension of the delta out into Fussach Bay, the area of Lake Constance has decreased by approximately $1.2 \mathrm{~km}^{2}$ in 50 years, and the average depth of Fussach Bay has decreased from 17.2 to $4.06 \mathrm{~m}$. The New Rhine Delta is composed primarily of silty sands; clean sands and pebble deposits are extremely rare. The average grain size decreases from top-set beds (silty sands) through foreset beds (silty sands and silt) to bottom-set beds (silt to clayey silt which grades into silty clay away from the delta). 


\subsubsection{Modelling}

We modelled sediment deposition of the New Rhine Delta for the period between 1900 and 2015. We obtained the morphological and sedimentological parameters from previous studies on Lake Constance and the Alpine Rhine such as Muller [1966]; Wessels et al. [2015a]; Wessels et al. [2015b]; Adami et al. [2016]; Wessels et al. [2016]. In particular, the New Rhine delta volume was calculated using the $3 \mathrm{~m}$ resolution Lake Constance bathymetry constructed by Wessels et al. [2015b], with ArcGIS used for volume calculation. The New Rhine delta is a Gilbert-type [Gilbert, 1890]. Grain size value (D50 and D90) are taken from Tockner et al. [2009] and Adami et al. [2016]. Input parameters are shown in paragraph 3.2.1 and in the spreadsheet provided in the supplementary material. For the New Rhine Delta, the calculated timescale are again about two factors different from the true timescale (predicted from modelling: 50 years; reality: 115 years), again within the range of expected uncertainty of sediment transport predictions.

\section{Jezero modeling}

The morphological elements suggest several possible scenarios of hydrological activity that are discussed in the Mangold et al. companion paper. Based on that discussion, we split the Neretva Vallis evolution history in two phases: phase 1 concerns the basin infilling just after the breaching of the western rim but before delta formation; phase 2 concerns the development of the delta. Herein we concentrate on the second phase because the first phase is constrained from detailed study by a cover in the crater of presumably volcanic origin. The aim of the modelling is therefore to constrain the period of hydrological activity from: a) observed morphology; and b) flow and sediment transport predictors in the entire active system of inflow, lake and outflow. All calculations are based on observed volumes and on slopes, widths, and lengths of feeder channels, channels on the delta and the eastern crater rim breach, as well as on a range of likely grain sizes.

The results of the simulation using relevant Neretva Vallis morphological and sedimentological parameters are shown in Table 1. Considering the volume detailed in Table 1, initially we find out its suspected filling times (Phase 1) followed a subsequent phase (Phase 2) of delta-formation [Kraal et al., 2008; Kleinhans et $a l ., 2010]$ Finally, the breach evolution is investigated.

\subsection{Phase 1 - Basin infilling (Full bank + Low Bank)}

We modelled two different scenarios for the Jezero basin infilling phase: one considering Neretva Vallis width and depth calculated in this work and another considering a more conservative (narrower) value of channel width calculated by previous authors [Fassett and Head, 2005; Ehlmann et al., 2008]. In this work we estimated Neretva Vallis width of $190 \mathrm{~m}$, channel depth of $5 \mathrm{~m}$, channel slope of 0.0097 and we considered various grain sizes: from pebble to fine sand (Table 1). The time required to fill the basin, considering a continuous flow within a $190 \mathrm{~m}$ width and $5 \mathrm{~m}$-depth channel, varies between 6,55 and 6,75 years depending on the grainsize considered.

\subsection{Phase 2 - Delta formation}

In this section we show a representative simulation using relevant Jezero morphological and sedimentological parameters listed in Table 1 . In particular we consider a $5 \mathrm{~km}^{3}$ delta volume as calculated in this study and as suggested by previous researchers [Fassett and Head, 2005; Ehlmann et al., 2008]. The eroded volume of the final and steepened part of the Neretva Vallis is of about $56 \mathrm{~km}^{3}$ (Mangold et al., companion paper), which is far greater than the sediment stored in the fan. We present two main scenarios that differ in channel width value. We again considered different D50 grain size from 0.25 to $20 \mathrm{~mm}$ (from fine sand to pebble). Morphological parameters used for calculations in both scenarios are listed in Table 1. In that phase grain size plays a major role for the delta timing: in fact calculated timescale vary by a factor of fifty depending on 
Accepted paper in Astrobiology - Vol. 8 (2020)

whether pebble or fine sands are input. All grain sizes reported hitherto are from distal landing sites (overview in Kleinhans [2005]) and to date the only genuine measured grainsize in a fluvio-lacustrine environment on Mars are those reported in Williams et al. [2013] measured by the Curiosity rover. We decided to test this model with different grain size in order to show its sensitivity (see spreadsheet in the supplementary material). In the absence of field data and based on the few indications that we have had from the Curiosity rover, in what appears to be a more alluvial environment than fluvial, we have preferred to adopt a conservative approach and to use the D50 values between 8 and $14 \mathrm{~mm}$ to calculate the minimum delta formation time. Calculated timescales for the Jezero delta with the above mentioned parameters range between 90 and 145 years. By adopting a more conservative channel width value $(50 \mathrm{~m})$, estimated by Fassett and Head [2005], and keeping the other parameters unchanged: the delta formation time varies between 330 and 550 years.

A 90-550 years for a fan-delta such as Jezero crater does not seem to be an underestimate when compared to the terrestrial case studies. For instance, A progradation rate of $15 \mathrm{~m} /$ year has been measured by Muller [1966] in the Rhine delta at Constance lake. For the $5 \mathrm{~km}$ long delta at Jezero, a duration of 100-500 years, would correspond to a progradation of 10 to $50 \mathrm{~m} /$ year, consistent with the example at Constance Lake.

There is evidence that the Jezero delta underwent intense erosion at the delta front [Goudge et al., 2015], which could mean a longer formation time if we consider that the delta extended to the areas where today we only see the remnants of a possible ancient delta front. Goudge et al. [2015] estimates a possible eroded delta to have originally been $7.8 \mathrm{~km}^{3}$ in volume. In this study were prefer a more conservative estimate and modelled a delta $15 \mathrm{~km}^{3}$ in volume, which represents the upper limit for the "delta volume" parameter in our modelling. For D50 values between 8 and $14 \mathrm{~mm}$ (pebble), keeping unchanged the morphological and sedimentological parameters and modifying only the delta volume (from $5 \mathrm{~km} 3$ (real actual delta) to $15 \mathrm{~km} 3$ (delta hypothesized on the basis of the remnants)), calculated timescale for the Jezero delta then range between 260 and 430 years, which is about three times longer than in the modelling of the deposits present today in the crater. If the calculation is conducted with the more conservative width $(50 \mathrm{~m})$, then the delta formation time ranges between 1000 and 1640 years.

\subsection{Outlet analyses}

In this section we establish whether the processes inherent to the Jezero outlet can further constrain the timescale of hydrological activity. It has previously been established that the sedimentary timescale of fan formation is far larger than the minimum hydrological timescale for the filling of the lake to the topmost level of the delta (Kleinhans et al., [2005]; Kleinhans et al., [2010]). The topographic gap between the top of the breach and the delta top makes it clear that at some point the lake overflowed. It is possible that lake overflow processes have the ability to do large amounts of erosional and depositional work in a short period of time, especially during the initial phases of dam breaching [Bretz, 1969; O'Connor and Baker, 1992; O'Connor and Beebee, 2009; Roda et al., 2014]. On Mars these overflow processes are thought to be characterized by very high discharges and rapid outlet canyon incision [Coleman, 2013; Roda et al., 2014; Coleman, 2015], including incision from multiple lake overflow floods (e.g., Salese et al. [2016]; Goudge et al. [2018]) and incision from long-term outflow (e.g., Holo and Kite [2017]).

The volume of sediment eroded from the rim was estimated using an ArcGIS 10.6 toolbox. This yields an average entire volume of $3 \mathrm{~km}^{3}$. From the adjacent rim height, it can be estimated that the pre-breach paleolake level reached at least $-2243 \mathrm{~m}$ in elevation and the post-breach water surface elevation was estimated as the base of the breach at $-2410 \mathrm{~m}$ in elevation, which is the same elevation of the Jezero delta top (Figure 2). The water volume drained from the lake during progressive breach incisions corresponding to the volume contained between -2243 and -2410 meters. This yields a minimum water volume of $238 \mathrm{~km}^{3}$ that must have been expelled from the crater lake during breaching. 
The flow flux out of the Jezero crater was likely sediment-poor, ponding water so that the sediment transport capacity of the flow was entirely available for erosion of the channels. This evident water scour is the reverse of the deposition of crater lake deltas from a sediment laden flow that enters a crater lake [Kleinhans, 2005; Kraal et al., 2008] as the gradient of sediment transport integrated over time is the same as the total displaced volume of sediment, allowing the calculation of the timescale [Ts] of formation directly from the volume of displaced sediment $\left[\mathrm{V}=3 \mathrm{~km}^{3}\right]$ and the sediment transport rate [Qs] (corrected for porosity) [Kleinhans, 2005].

The sediment transport rate is calculated from the flow flux through the channel. The following steps were applied to calculate flow flux: a) width, flow depth and gradient of the channel are estimated from HRSC topography (Figure 2a); b) throughout morphological analyses of the breach we identified three main terraces that led us to hypothesize at least three different phases within the same event (Figure 2). These three phases differ in channel depth and width. Furthermore, we model two different breach slope scenarios: 1) considering the slope $(0.02)$ of the actual outlet channel (Figure 2 - Profile E-F); 2) considering a hypothetical pre-breach slope (0.05), estimated through the average of the rim slopes to the north and south of the breach. In both cases are steep breaches and in this situation the flow is usually critical (Froude number $=$ 1).

The numerical modelling of crater rim behaviour is subject to great uncertainty due to the lack of knowledge about the grain-size distribution of materials transported and whether the eroding crust was bedrock, unconsolidated or comprised weakly cemented sediment. For this reason we assume a D50 rim grain size of 0.1 meters and D90 of $0.6 \mathrm{~m}$, same values as used for the breach in Aram Chaos from Roda et al. [2014]. Maximum flow depth is estimated from terraces heights, with hydraulic roughness subsequently calculated.

The water depth inferred from terraces $(\mathrm{h})$ is within the expected range based on the resulting width-depth ratio of the flow (about 20 for narrow terrestrial gravel bed rivers of similar slope) and results in reasonable sediment mobility (expressed as the dimensionless Shields number, Table 2) [Kleinhans, 2005]. We assumed near-critical flow (Froude number around 0.9) and use this to confine the water depth. In fact, on such steep slopes flow is typically critical, resulting in very efficient sediment transport.

We modelled the outlet with parameter settings and choices for independent variables (depth, slope) and the friction relation for these steep slopes. The resulting erosion timescale was always about three orders of magnitude larger than the time needed for the water to flow out of the crater. Unlike the crater breaching case of Roda et al. [2014], where the authors apply the same method that we use in this work, there was no reasonable combination of slope, grain size and friction for which the timescales of water evacuation and breach erosion overlapped. This means that any outflow with erosive power on the crater rim would have emptied the necessary disc of water faster than that flow could have deepened the breach. In order for the breaching and the delta formation to be coeval, a much larger discharge would be required from the hinterland (in contradiction with outflow calculations).

\subsubsection{Outflow evidence's implications}

The implication of the timescale calculations is that the breach could not have formed from one overflowing event with the volume of the disc of water, and instead a much longer process of lake activity and spilling is required. This means that the breach formation was not limited by the amount of water within the lake, but only by the flow discharge from the Neretva Vallis. Furthermore, either the discharge must have been very large to form the breach, or flow must have been acting on the crater wall for a sustained period of time.

On the basis of process knowledge for terrestrial breaches certain constraints are possible. The large dimensions of the lake (58 km in diameter) mean it is possible to ignore the effects of both possible floods or 
constant flow, as these are buffered by incoming floods and cause limited spilling only (with the exception of some seiches during storms and potential small-scale tsunamis in the aftermath of the crater wall collapse). Regardless of the details, this process must have taken a substantial period of time, or such a large discharge as to be incompatible with the late-stage channel and delta. The breach could not have formed in the same event that formed the present Jezero fan deposit, but must have formed in earlier events associated with the entire channel system to the west (before emplacement of the volcanic layer on the crater floor) [Mangold et al., companion paper]. During the time needed for delta formation, erosion of the breach is negligible. We therefore assume constant breach elevation and constant lake level during the delta-forming event.

These findings present certain contradictions to previous work: Fassett and Goudge [2017] suggest that most of the flood-related geomorphic work happened within two weeks while Holo and Kite [2017] suggest that the observed outlet can be carved in decades to centuries of progressive bed load as the delta forming flows filled the lake. Both estimates are problematic given the combination of outflow and sediment transport capacity of that outflow. The Aram Chaos side-channel case, conversely, did likely form in one outflow event because a much larger volume of water became available and the crater rim was far steeper [Roda et al., 2014]. All such calculations depend on the nature of the sediment, unconsolidated rock or impact regolith that is eroded (see page 112 on rock and 114 on breaching in Marra et al. [2014]).

\subsection{Paleo-evaporation rate on Mars and intermittency}

The timescale of lake filling would have likely been additionally affected by evaporation. On Earth 57\% of all precipitations on land evaporate and in warm and dry climates up to $96 \%$ of the yearly precipitation may evaporate [Hendriks, 2010]. Evaporation is therefore a fundamental parameter in evaluating fluvio-lacustrine lifetimes. On the one hand, high evaporation rates would empty the lake faster following the shutdown of the feeder system. Conversely, given the constraint that the lake must have filled up to the lowest level of the breach in Jezero, evaporation would mean a larger filling timescale with otherwise matching discharge. However, evaporation strongly depends on weather and any estimates here would therefore invoke significant speculation. There are two widely used methods of estimating evaporation rate for terrestrial systems: 1) pan evaporation; and 2) the more complex but realistic Penman-Monteith equation [Hendriks, 2010].

Pan evaporation is common practice in water resource management for dams and reservoirs. A pan coefficient is applied to measured pan evaporation rates in order to derive equivalent evaporation from the water storage of interest. This methodology is widely used due to its simplicity though results in a number of limitations [Kohler et al., 1955; Shuttleworth, 1992; Lowe et al., 2009]. As stated by Lowe et al. [2009], the $95 \%$ probability intervals surrounding the estimates of reservoir evaporation on Earth are as large as $\pm 40 \%$ of the best estimate using the pan method. Furthermore, one of the main uncertainty of this method is due to pan coefficient itself [Lowe et al., 2009] which is between 0 and 1, 0 in the case of warm climate and low humidity and 1 for cold climate and high humidity [Hendriks, 2010]. The evaporation from a pan is a good indicator of the evaporation from the surrounding environment only when land-surface moisture is in ample supply [Brutsaert, 1982; Brutsaert and Parlange, 1998].

More complex equations, such as for example Penman-Monteith equation, are frequently used to estimate evaporation on Earth's open lakes, taking into account the saturation of air flowing over the lake which act to reduce evaporation. This approach, while more applicable than pan evaporation on a large lake such as Jezero, requires additional knowledge of several environmental parameters. The main and most important input parameters of these equations are: wind speed, air temperature, atmosphere pressure, incoming short wave radiation, relative humidity, and atmosphere density. While estimates in the literature suggest that evaporation modifies the hydrological timescale as much as grainsize changes the sedimentary timescale [Wallace and Sagan, 1979; Sears and Chittenden, 2005; Sears and Moore, 2005], the necessity for variables 
that are hard to estimate for an early Mars makes it impossible to estimate paleo-evaporation rates with any degree of confidence.

For example, Irwin et al. [2015] estimated evaporation rate for the Eberswalde Martian case using pan evaporation. They used a pan coefficient of 0.7 and today's parameters (e.g., Solar insolation) to estimate a possible evaporation rate for the Martian paleoenvironment. This resulted in an evaporation rate range of $0.1-$ $1 \mathrm{~m} /$ year. While this is the best estimate possible with what is known for Martian conditions, the evaporation rate is based on present meteo-environmental parameters rather than those during the activity of the Eberswalde system, and the obtained value (even for Earth) is large. Note that the greater the temporal duration of a system (i.e., lake), the more significant the value of evaporation rate is for long term predictions. If the timescale of delta formation was only of the order of years or decades, even such high evaporation would not have significantly modified the order of magnitude of the timescale. We encounter the same issue for the intermittency: if the lake formed in a catastrophic event then intermittency is not as relevant, but if it took centuries then it is likely discharge fluctuated over seasonal or longer time periods.

\subsection{Interpretation}

Based on the evidence found here and in the companion work of Mangold et al., we can deduce that the long Neretva Vallis $(200 \mathrm{~km})$ that drained within the Jezero basin was not entirely related with the present delta. The volume of the missing sediments $\left(56 \mathrm{~km}^{3}\right)$ within the entire Neretva Vallis is ten times larger than the present delta volume $\left(5 \mathrm{~km}^{3}\right)$, even if the remnants are taken into account. The fact that the volume of the delta is almost the same as the eroded sediment volume from the breach is coincidental because the mechanisms cannot be causally linked. Much more likely is the hypothesis that the current delta is linked to flow event(s) which occurred in the relatively late stage, large valley activity, as well as reliably witnessed by the presence of knickpoints within the terminal part of the Neretva Vallis (Mangold et al., companion paper). Other fluvial sedimentological evidence (e.g., bars) are also evident upstream. We consider it most probable that flow in the Neretva Vallis would have been shallow, wide and relatively weak. This is consistent with the findings of the companion paper (Mangold et al., companion paper): local sediment deposits forming bars but constrained in depth by the rocky valley floor, and a tendency to braid when the valley is wide enough. Furthermore, large discontinuities in channel floor slope suggest that this is not an alluviated equilibrium channel with erodible sediment in the floor, but a bedrock valley formed by an earlier and likely much larger fluvial epoch. The absence of ubiquitous sediment on the valley floor is additional evidence that the sediment stored in the delta was either sourced from the sparse cover of loose sediment in the upstream valley system, or from erosion of the valley floor immediately upstream of the crater lake.

In Figure 3 we summarize a hypothetical evolution of the Jezero basin. The crater was initially filled by the upstream $200 \mathrm{~km}$-long Neretva Vallis, acting as a closed basin. At some point the eastern rim of the crater breached in at least three episodes from $-2243 \mathrm{~m}$ until $-2410 \mathrm{~m}$. From then on, the crater floor transformed to an open lake filled for a while with sediment-poor water and then started the growth of the Jezero deposits. According to the evidence of the sediment at the mouth of the Neretva Vallis, initially and briefly as an alluvial fan and later as a delta. Since the top level of the delta is precisely at the level of the breach, the lake probably overflowed and the delta continued to develop for a while longer. Due to the overflowing condition we cannot constrain an optimum timescale for the delta formation by the maximum water level timescale (as is possible for stepped fans). We are more uncertain about the timescale so we apply a range of grain sizes for a number of channel widths, the main uncertainty in our calculation. We approximate grain size within a logical range [Sklar and Dietrich, 2004; Parker et al., 2007]). We have estimates of water depth from the present observations of bar heights (that would have been submerged only during flood) and terraces. Our finding, that the sediment timescale is larger than the water timescale is in agreement with our hypothesis so we end up with the above uncertainty as the range. Then, finally, the lake remains wet while the upstream feeder system has shut off until the water has percolated/seeped out and/or entirely evaporated. Even if we 
Accepted paper in Astrobiology - Vol. 8 (2020)

assume a high evaporation rate of 0.1-1 m per year [Hendricks, 2010], that still adds to the timescale calculation.

\subsection{Astrobiological implications for rover exploration}

The deposits within the MSL 2020 landing site could have preserved biosignatures to investigate on the spot and sample for a return mission. On Earth, microorganisms have pervaded all wet, surface and subsurface environments. In subaqueous environments, microorganisms commonly exist dually in the water column and in sediment pore spaces or as attached biofilms. In addition, sedimentary processing such as hydrodynamic sorting, as evident in terrestrial fluvial and deltaic environments, may concentrate biologically derived carbonaceous particles into fine-grained, organic-rich horizons in sedimentary beds. Among sedimentary systems on Earth, lacustrine (perennial) and deltaic systems have been estimated as high for supporting organic matter (OM) formation, concentration, and preservation [Summons et al., 2011]. This is primarily because of the diverse and prolific microbial life that exist in lakes and the existence of hydraulic gradients across both deltaic upper plains and slopes: organic material sequestered preferentially by the fine-grained sediments of the distal flood plains, and of the bottomsets at the toe of the delta foreslope. By analogy, the deltaic-lacustrine closed basin of western Jezero affords a definite potential for retention of transported and in situ organics and environments that hydrodynamically concentrate organics. Assuming that the lake and delta formed by the processes and on a timescale of decades to millennia (as in our favored interpretation), the following astrobiological implications emerge. In the first place, the gravelly delta itself is an environment poorly favorable to life, because of the high energy in the flow and on the bed. In contrast, it is quite likely that fine-grained sediments were deposited downstream of the delta foreset in bottomsets and on the lake floor. The existence of such fine-grained sediments has been inferred on Mars from lander data, from missing sediment volume in perfectly sediment-trapping crater lakes, and from the ubiquitous fine cover north of the dichotomy [Kleinhans, 2005; Hauber et al., 2013]. Such fine-grained sediment potentially provided the nutrients, and the low hydrodynamic energy on the lake bed to make this environment astrobiologically significant.

\section{Conclusion}

The geological and hydrological analyses performed on the Jezero crater and delta deposits indicate that the minimum lake filling timescale with $463 \mathrm{~km}^{3}$ of sediment-poor water until $-2243 \mathrm{~m}$ is between $6.55-27.36$ years depending on the channel width (see spreadsheet in the supplementary material). The minimum lake delta formation timescale for $5 \mathrm{~km}^{3}$ up to $-2410 \mathrm{~m}$ in elevation is $90-150$ years with a channel $190 \mathrm{~m}$ width and 330-550 years for a channel 50 meters wide. These minimum estimations have been calculated without consideration of intermittency/evaporation/groundwater effects because it is impossible to constrain the impact of these (extinct) processes. The Jezero fan formed as a fluvial delta deposited over a fluvial fan by suspended bed load material, but the timescale uncertainty depends more on unknown grain size than on channel geometry. The discharge of the Neretva Vallis that has been used to form the delta is much smaller than that of the outlet. This confirms that the delta formation and the breach are not coeval because if we compare the two discharges, the basin empties much faster than it fills. Furthermore, the timescale to empty the basin is far smaller than the time scale to carve the breach. This implies that the basin acted as a closed (steady-state) basin for an unknown period with a water table at least at $-2243 \mathrm{~m}$ and then it had at least three catastrophic collapses or it overflowed for a long (unknown time) in order to carve out the breach. The increase in channel size decreases the duration of the system and further corroborates this hypothesis. The time needed to erode the volume of sediment from the breach $\left(3 \mathrm{~km}^{3}\right)$ and to carve the outlet removing its 12 $\mathrm{km}^{3}$ of sediments, compared to the discharge and the time required to empty the basin, suggest a much longer duration of the inlet (Neretva Vallis) or the breach event. The breach therefore formed over several distinct events sourced by the channel system upstream of the delta, with the delta itself developing far later. 
Accepted paper in Astrobiology - Vol. 8 (2020)

Our findings about a short duration of formation of the depositional fan of several hundred years do not support the idea of a perennial lake that would have been permissive of the incipience and development of any microbial life. Furthermore, from our analysis, given the high channel discharges, it emerges that the delta toeset dominated by clastic, coarse-deposits (coarse sandstones, conglomerates), is of debatable exobiological significance because of the oxidizing fluids moving through the porous deposits. Conversely, lake floor deposits, paleolake margins and/or delta bottomset are characterised by fine sediments, not trapped in the delta. The latter area is of stronger exobiological significance than the fan: with the suspended sediment serving as food for potential microscopic life, and the lake floor sediment providing a substrate with good preservation potential (e.g. washload sediment settling). However, it should be noted that the Jezero lake may have existed for a long while prior to this ultimate fluvial gasp, and in the short-in-time western Jezero fan deposition may have thus initiated into an already biologically active environments. The short temporal duration of the system hypothesized from this study does not preclude the possibility of discovering in situ organics in the fine-grained deposits, but does reduce the probability of success.

Supplementary Information. is linked to the online version of the paper.

Acknowledgements. Francesco Salese is supported by Marie Curie Individual Postdoctoral Fellowship (WET_MARS, Grant Agreement No. 795192). The data (HRSC, CTX, HiRISE, MOLA) that support the findings of this study were obtained freely from the Planetary Data System (PDS) and are publicly available online at https://pds.nasa.gov/index.shtml. The authors wish to thank MRO and HRSC team for these data. Satellite imagery and the Extended Data were generated with ISIS 3 (Integrated Software for Imagers and Spectrometers) available online at https://isis.astrogeology.usgs.gov. All these data were integrated into ArcGIS 10.6 project. French authors are granted by the Centre National d'Etudes Spatiales (CNES). Région Pays de la Loire through the GeoPlaNet project (convention $\mathrm{N}^{\circ}$ 2016-10982) also supported this work. We acknowledge discussions within the rover 2020 team.

Author Information. Correspondence and requests for materials should be addressed to Francesco Salese (f.salese@uu.nl).

Author Disclosure Statement. No competing financial interests exist 


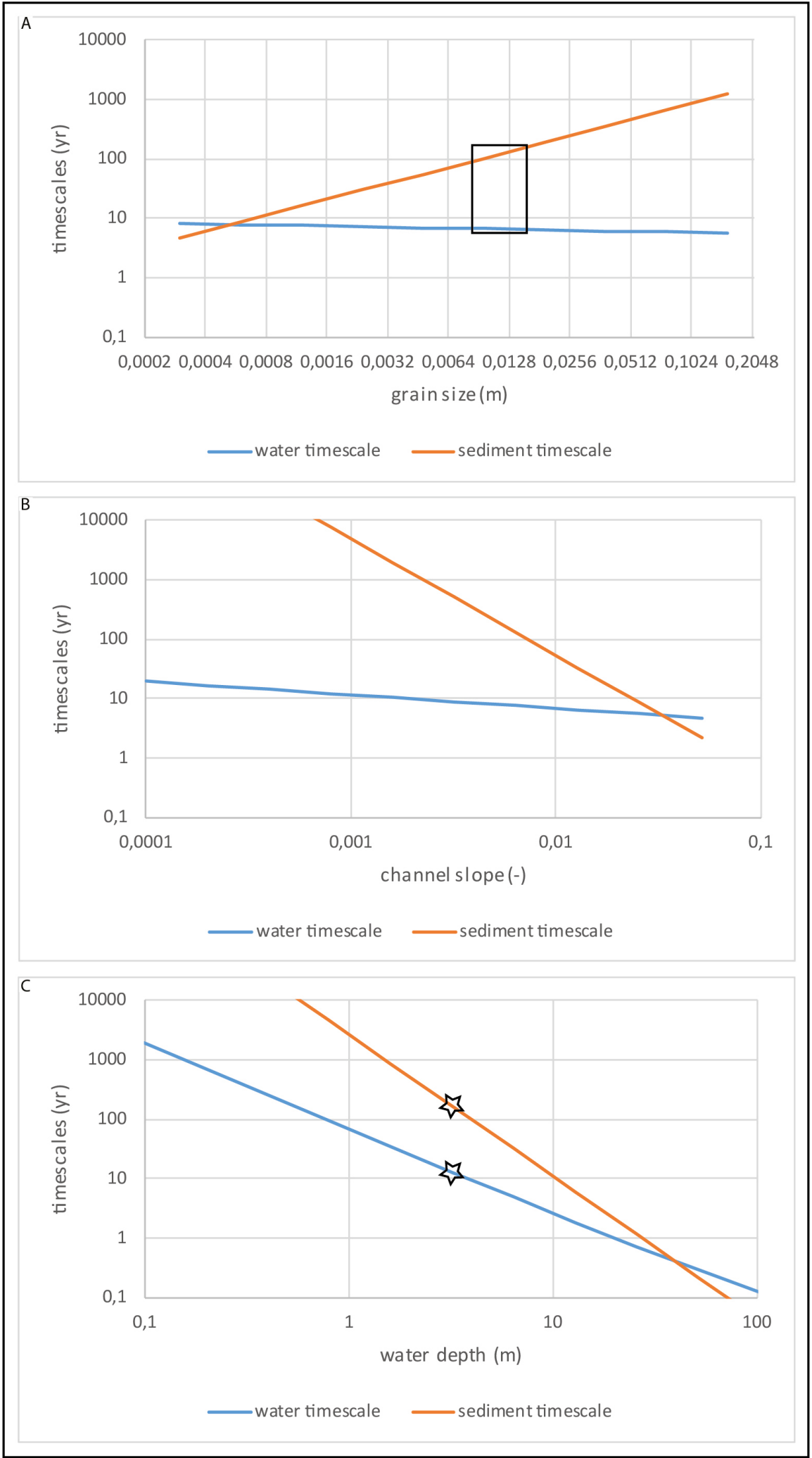

Figure 1 Main parameters (grainsize, channel slope, channel depth) used in the hydrological modelling that strongly affect the transport predictors. A) Grain size vs timescale. Based on different grain size, the blue line indicates the amount of time needed to fill the basin whereas the orange line displays the timing to form the delta. The black box indicates the grain-size range that we considered to estimate the Jezero timing (see main text). B) Channel slope vs timescale. The slope is a crucial parameter for estimating delta timescale, as is evident from this plot. Reducing the slope by a factor of 10 implies a timescale reduction by a factor of 100 . 
Accepted paper in Astrobiology - Vol. 8 (2020)

Careful and high-resolution estimates of the channel slope is fundamental to better constrain the timescale of the Jezero paleo fluvio-lacustrine system. C) Channel depth vs timescale. Transport predictors are very sensitive to this parameter, reducing the slope by a factor of 10 implies a timescales reduction by a factor of 100. The black stars indicate the 5 meters channel depth that we measured through the HiRISE DEM, which we used for the timing estimate.
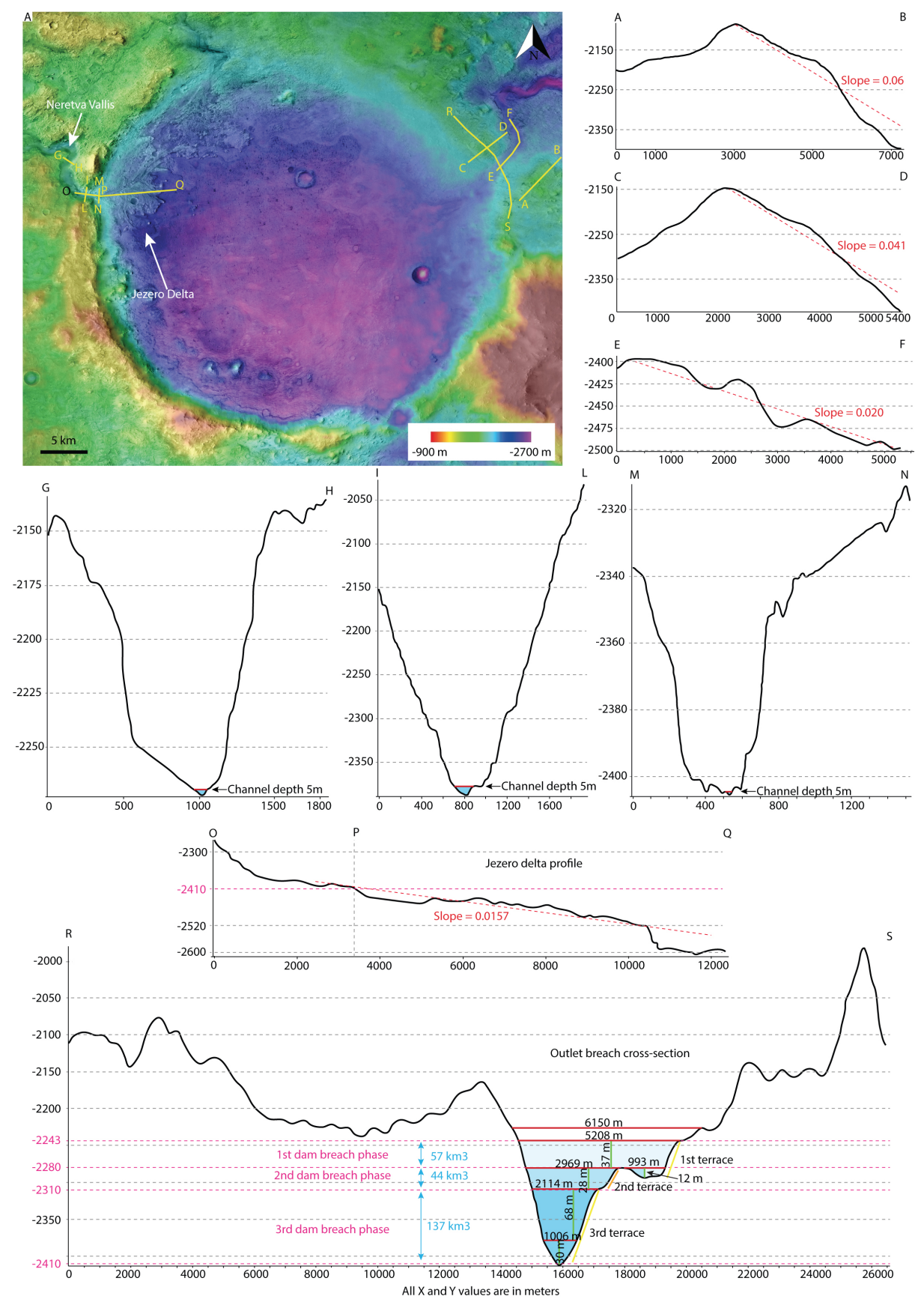

Figure 2 A) Location map of the topographic profiles within the Jezero crater. Profiles A-B / C-D show the pre-breach rim slope; D-E display outlet channel slope; G-H / I-L / M-N indicate the inlet (Neretva Vallis) depth at three different locations (a zoom of these profiles is in the supplementary material); O-Q shows the delta slope; R-S shows the breach profile with the three main stages in different tones of blue that are described in the main text. 


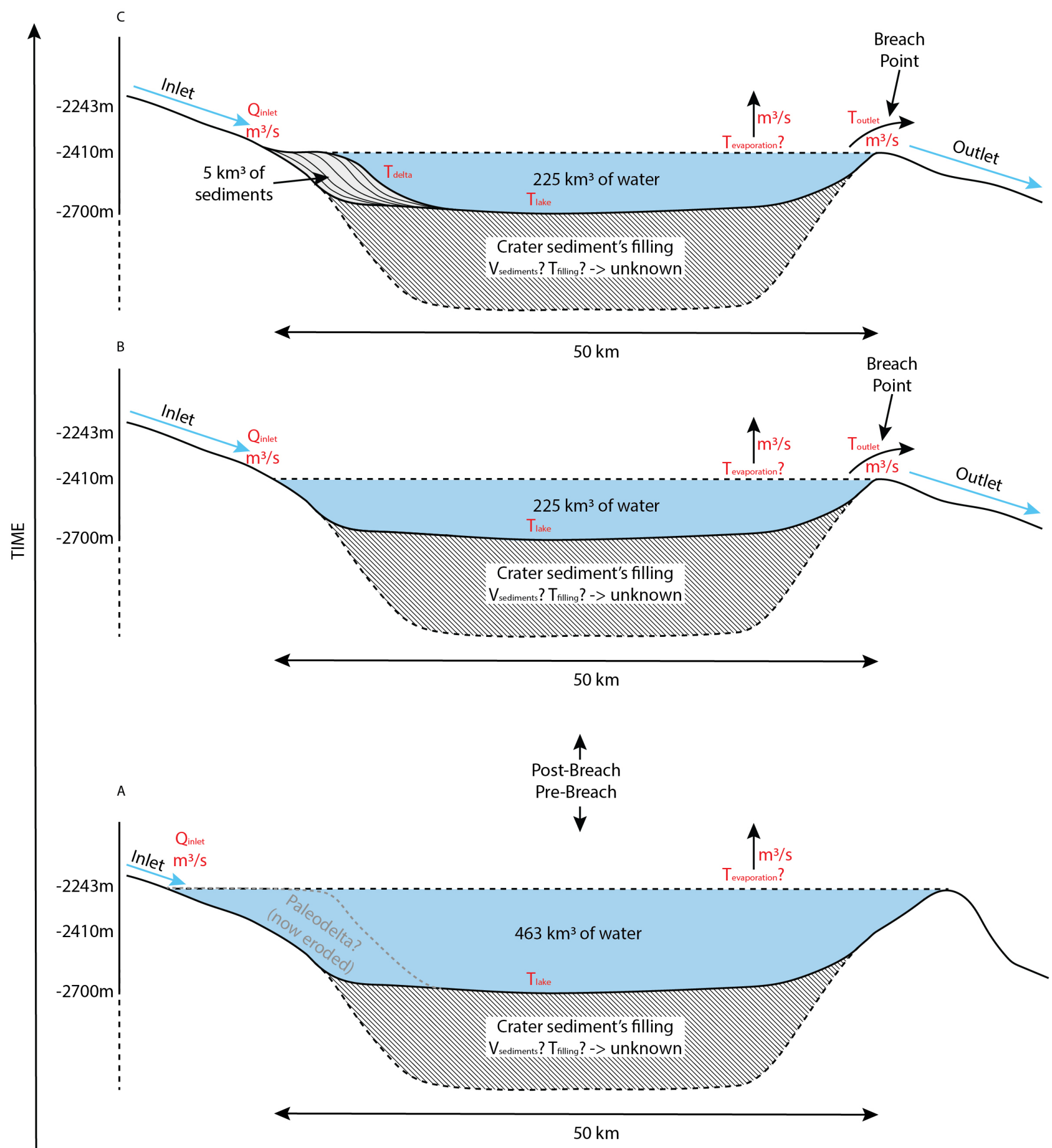

Figure 3 Proposed model of Jezero basin evolution, independent (black) and dependent (red) variables are indicated in the figure. From the bottom to the top: A) Pre-breach stage: the basin was filled at least with 463 
$\mathrm{km}^{3}$ up to $-2243 \mathrm{~m}$ in elevation. The presence of an older and bigger paleodelta than we see at present could be supposed but is not considered as there is no evidence of a paleodelta at this topographic elevation. B) Post-breach phase: the water level drop to -2410 and the water volume within the lake is reduced to $225 \mathrm{~km}^{3}$. C) Deposition of the Jezero delta. Note that the top of the Jezero delta has the same elevation of the bottom of the breach. See main text for further description.

Table 1 List of parameters and scenarios used to unravel the timing and evolution of the Jezero delta.

\begin{tabular}{|c|c|c|c|c|c|c|c|c|c|c|c|c|c|c|}
\hline \multirow[t]{2}{*}{$\begin{array}{l}\text { Calcu } \\
\text { lation }\end{array}$} & \multirow[t]{2}{*}{ Parameters } & \multirow[t]{2}{*}{$\begin{array}{l}\text { Uni } \\
\text { ts }\end{array}$} & \multicolumn{4}{|c|}{ Parameters from this work } & \multicolumn{4}{|c|}{$\begin{array}{l}\text { Width from Fasset and Head } \\
2005 \text { \& Ehlmann et al., } 2008\end{array}$} & \multicolumn{4}{|c|}{$\begin{array}{l}\text { Parameters from this work \& } \\
\text { estimated delta volume of } 15 \mathrm{~km}^{3} \\
\text { - Delta until remnants (Goudge } \\
\text { et al., 2015) }\end{array}$} \\
\hline & & & 1 & 2 & 3 & 4 & 5 & 6 & 7 & 8 & 9 & 10 & 11 & 12 \\
\hline \multirow[t]{10}{*}{ Input } & Channel & $\mathrm{m}$ & 190 & 190 & 190 & 190 & 50 & 50 & 50 & 50 & 50 & 50 & 50 & 50 \\
\hline & width & $\mathrm{m}$ & 5 & 5 & 5 & 5 & 5 & 5 & 5 & 5 & 5 & 5 & 5 & 5 \\
\hline & Channel & $\mathrm{m} /$ & 0,00 & 0,00 & 0,00 & 0,00 & 0,009 & 0,009 & 0,009 & 0,0097 & 0,009 & 0,009 & 0,009 & 0,009 \\
\hline & depth & $\mathrm{m}$ & 97 & 97 & 97 & 97 & 7 & 7 & 7 & 0,0015 & 7 & 7 & 7 & 7 \\
\hline & Channel & $\mathrm{m} /$ & 0,00 & 0,00 & 0,00 & 0,00 & 0,001 & 0,001 & 0,001 & 30 & 0,001 & 0,001 & 0,001 & 0,001 \\
\hline & slope & $\mathrm{m}$ & 15 & 15 & 15 & 15 & 5 & 5 & 5 & 5 & 5 & 5 & 5 & 5 \\
\hline & Fan-delta & $\mathrm{km}^{2}$ & 30 & 30 & 30 & 30 & 30 & 30 & 30 & 3 & 58 & 58 & 58 & 58 \\
\hline & slope & $\mathrm{km}^{3}$ & 5 & 5 & 5 & 5 & 5 & 5 & 5 & & 15 & 15 & 15 & 15 \\
\hline & $\begin{array}{l}\text { Fan delta } \\
\text { surface }\end{array}$ & $\mathrm{km}^{3}$ & 3 & 3 & 3 & 3 & 3 & 3 & 3 & 463,7 & 3 & 3 & 3 & 3 \\
\hline & $\begin{array}{l}\text { Fan-delta } \\
\text { volume } \\
\text { Eroded } \\
\text { sed. valley } \\
\text { volume } \\
\text { Basin } \\
\text { volume (- } \\
2243 \mathrm{~m})\end{array}$ & $\mathrm{km}^{3}$ & $\begin{array}{c}463 \\
7\end{array}$ & $\begin{array}{c}463 \\
7\end{array}$ & $\begin{array}{c}463 \\
7\end{array}$ & $\begin{array}{c}463 \\
7\end{array}$ & 463,7 & 463,7 & 463,7 & & 463,7 & 463,7 & 463,7 & 463,7 \\
\hline Sedi & Grain size & $\mathrm{m}$ & 0,01 & 0,01 & 0,01 & 0,00 & 0,014 & 0,012 & 0,01 & 0,008 & 0,014 & 0,012 & 0,01 & 0,008 \\
\hline ment & (D50) & $\mathrm{m}$ & 4 & 2 & 0,05 & 8 & 0,07 & 0,06 & 0,05 & 0,04 & 0,07 & 0,06 & 0,05 & 0,04 \\
\hline $\begin{array}{l}\text { trans } \\
\text { port }\end{array}$ & $\begin{array}{l}\text { Grain size } \\
\text { (D90) }\end{array}$ & & 0,07 & 0,06 & & 0,04 & & & & & & & & \\
\hline Disch & Friction & - & 0,25 & 0,25 & 0,26 & 0,26 & 0,25 & 0,25 & 0,26 & 0,26 & 0,25 & 0,25 & 0,26 & 0,26 \\
\hline arge & factor & $\mathrm{m} / \mathrm{s}$ & 2,4 & 2,3 & 2,3 & 2,3 & 2,2 & 2,2 & 2,2 & 2,1 & 2,2 & 2,2 & 2,2 & 2,1 \\
\hline calcul & Velocity & - & 0,55 & 0,54 & 0,54 & 0,53 & 0,51 & 0,51 & 0,50 & 0,50 & 0,51 & 0,51 & 0,50 & 0,50 \\
\hline ation & $\begin{array}{l}\text { Froude } \\
\text { number } \\
\text { Discharge }\end{array}$ & $\begin{array}{l}\mathrm{km}^{3} \\
/ \mathrm{da} \\
\mathrm{y}\end{array}$ & 2246 & 2227 & 2205 & 2178 & 553 & 549 & 543 & 537 & 553 & 549 & 543 & 537 \\
\hline Bedlo & Shields & - & 0,15 & 0,17 & 0,19 & 0,21 & 0,14 & 0,15 & 0,17 & 0,19 & 0,14 & 0,15 & 0,17 & 0,19 \\
\hline ad & parameter & -3 & 0,34 & 0,41 & 0,49 & 0,63 & 0,29 & 0,34 & 0,42 & 0,53 & 0,29 & 0,34 & 0,42 & 0,53 \\
\hline trans & Nondim. & $\mathrm{km}^{3}$ & 0,00 & 0,00 & 0,00 & 0,00 & 0,000 & 0,000 & 0,000 & 0,0000 & 0,000 & 0,000 & 0,000 & 0,000 \\
\hline \multirow[t]{3}{*}{ port } & Transport & $/ d a$ & 0035 & 0033 & 0031 & 0028 & 0078 & 0074 & 0069 & 0629 & 00787 & 00742 & 00690 & 00629 \\
\hline & rate & y & 6 & 4 & 0 & 2 & 7 & 2 & 0 & 7372 & 6078 & 6395 & 6808 & 7372 \\
\hline & $\begin{array}{l}\text { Volum. } \\
\text { Transport } \\
\text { rate } \\
\text { Water/sedi } \\
\text { ment ratio }\end{array}$ & - & 5458 & 5755 & 6140 & 6663 & 6078 & 6395 & 6808 & & & & & \\
\hline $\begin{array}{l}\text { Total } \\
\text { load } \\
\text { trans } \\
\text { port }\end{array}$ & $\begin{array}{l}\text { Shields } \\
\text { parameter }\end{array}$ & - & 1,4 & 1,6 & 1,9 & 2,4 & 1,4 & 1,6 & 1,9 & 2,4 & 1,4 & 1,6 & 1,9 & 2,4 \\
\hline
\end{tabular}


Accepted paper in Astrobiology - Vol. 8 (2020)

\begin{tabular}{|c|c|c|c|c|c|c|c|c|c|c|c|c|c|c|}
\hline $\begin{array}{l}\text { Suspe } \\
\text { nsion }\end{array}$ & $\begin{array}{l}\text { Nondim. } \\
\text { Transport }\end{array}$ & $\mathrm{km}^{3}$ & $\begin{array}{c}0,9 \\
0,00\end{array}$ & $\begin{array}{c}1,3 \\
0,00\end{array}$ & $\begin{array}{c}2,0 \\
0,00\end{array}$ & $\begin{array}{c}3,5 \\
0,00\end{array}$ & $\begin{array}{c}0,9 \\
0,000\end{array}$ & $\begin{array}{c}1,3 \\
0,000\end{array}$ & $\begin{array}{c}2,0 \\
0,000\end{array}$ & $\begin{array}{c}3,5 \\
0,0000\end{array}$ & $\begin{array}{c}0,9 \\
0,000\end{array}$ & $\begin{array}{c}1,3 \\
0,000\end{array}$ & $\begin{array}{c}2,0 \\
0,000\end{array}$ & $\begin{array}{c}3,5 \\
0,000\end{array}$ \\
\hline domi & rate & /da & 0095 & 0109 & 0128 & 0156 & 0251 & 0288 & 0338 & 413 & 0251 & 0288 & 0338 & 0413 \\
\hline \multirow[t]{2}{*}{ nated } & Volum. & $y$ & 3 & 3 & 6 & 8 & 1907 & 1649 & 1388 & 1124 & 1907 & 1649 & 1388 & 1124 \\
\hline & $\begin{array}{l}\text { Transport } \\
\text { rate } \\
\text { Water/sedi } \\
\text { ment ratio }\end{array}$ & - & 2037 & 1760 & 1482 & 1200 & & & & & & & & \\
\hline $\begin{array}{l}\text { Form } \\
\text { ative } \\
\text { time } \\
\text { scale } \\
\end{array}$ & $\begin{array}{l}\text { Time scale } \\
\text { to filling } \\
\text { basin until - } \\
2243\left(\mathrm{H}_{2} \mathrm{O}\right)\end{array}$ & $\begin{array}{l}\text { yea } \\
\text { rs }\end{array}$ & 6,55 & 6,6 & 6,65 & 6,75 & 26,55 & 26,76 & 27,03 & 27,36 & 26,55 & 26,76 & 27,03 & 27,36 \\
\hline $\begin{array}{l}\text { Form } \\
\text { ative } \\
\text { time } \\
\text { scale }\end{array}$ & $\begin{array}{l}\text { Time scale } \\
\text { to form } \\
\text { delta }\end{array}$ & $\begin{array}{l}\text { yea } \\
\text { rs }\end{array}$ & $\begin{array}{c}143 \\
6\end{array}$ & $\begin{array}{c}125 \\
2\end{array}$ & $\begin{array}{c}106 \\
5\end{array}$ & 87,3 & 545,8 & 475,8 & 404,5 & 331,7 & $\begin{array}{c}1637 \\
3\end{array}$ & $\begin{array}{c}1427 \\
4\end{array}$ & $\begin{array}{c}1213 \\
6\end{array}$ & 995,0 \\
\hline
\end{tabular}

Table 2 List of scenarios for the three different phases of the Jezero crater breach.

\begin{tabular}{|c|c|c|c|c|c|c|c|c|c|c|}
\hline \multirow{3}{*}{ Calculation } & \multirow{3}{*}{ Parameters } & \multirow{3}{*}{ Units } & \multirow{2}{*}{\multicolumn{8}{|c|}{ Scenario Phase 1}} \\
\hline & & & & & & & & & & \\
\hline & & & 1 & 2 & 3 & 4 & 5 & 6 & 7 & 8 \\
\hline \multirow[t]{3}{*}{ Input } & Channel width & $\mathrm{m}$ & 4000 & 4000 & 4000 & 4000 & 4000 & 4000 & 4000 & 4000 \\
\hline & Channel depth & $\mathrm{m}$ & 5 & 10 & 15 & 20 & 25 & 30 & 35 & 37 \\
\hline & Channel slope & $\mathrm{m} / \mathrm{m}$ & 0,032 & 0,038 & 0,042 & 0,045 & 0,048 & 0,05 & 0,052 & 0,053 \\
\hline & Friction factor & - & 0,31 & 0,37 & 0,41 & 0,44 & 0,47 & 0,49 & 0,51 & 0,52 \\
\hline \multirow{3}{*}{ calculation } & Velocity & $\mathrm{m} / \mathrm{s}$ & 3,9 & 5,5 & 6,7 & 7,8 & 8,7 & 9,5 & 10,3 & 10,6 \\
\hline & Froude number & - & 0,9 & 0,9 & 0,9 & 0,9 & 0,9 & 0,9 & 0,9 & 0,9 \\
\hline & Discharge & $\mathrm{km}^{3} /$ day & 6,7 & 19,0 & 34,9 & 53,7 & 75,1 & 98,6 & 124,1 & 135,0 \\
\hline \multirow{4}{*}{$\begin{array}{l}\text { Bedload } \\
\text { transport }\end{array}$} & Shields parameter & - & 0,12 & 0,19 & 0,24 & 0,29 & 0,34 & 0,38 & 0,42 & 0,44 \\
\hline & $\begin{array}{l}\text { Nondim. Transport } \\
\text { rate }\end{array}$ & - & 0,23 & 0,49 & 0,75 & 1,05 & 1,36 & 1,66 & 1,96 & 2,10 \\
\hline & $\begin{array}{l}\text { Volum. Transport } \\
\text { rate }\end{array}$ & $\mathrm{km}^{3} /$ day & 0,0094 & 0,0204 & 0,0320 & 0,0440 & 0,0567 & 0,0692 & 0,0821 & 0,0876 \\
\hline & $\begin{array}{l}\text { Water/sediment } \\
\text { ratio }\end{array}$ & - & 716 & 932 & 1090 & 1220 & 1325 & 1425 & 1512 & 1540 \\
\hline $\begin{array}{l}\text { Total load } \\
\text { transport }\end{array}$ & Shields parameter & - & 0,6 & 1,5 & 2,5 & 3,6 & 4,8 & 6,0 & 7,3 & 7,8 \\
\hline \multirow[t]{3}{*}{$\begin{array}{l}\text { Suspension } \\
\text { dominated }\end{array}$} & $\begin{array}{l}\text { Nondim. Transport } \\
\text { rate }\end{array}$ & - & 0,1 & 0,8 & 2,4 & 5,6 & 10,8 & 18,0 & 28,1 & 33,3 \\
\hline & $\begin{array}{l}\text { Volum. Transport } \\
\text { rate }\end{array}$ & $\mathrm{km}^{3} /$ day & 0,004 & 0,032 & 0,102 & 0,232 & 0,449 & 0,752 & 1,173 & 1,391 \\
\hline & $\begin{array}{l}\text { Water/sediment } \\
\text { ratio }\end{array}$ & - & 1547 & 597 & 342 & 231 & 167 & 131 & 106 & 97 \\
\hline Erosion & $\begin{array}{l}\text { Sediment breach } \\
\text { volume }\end{array}$ & $\mathrm{km}^{3}$ & 3 & 3 & 3 & 3 & 3 & 3 & 3 & 3 \\
\hline Discharge & Inlet & $\mathrm{km}^{3} /$ day & 0,2 & 0,2 & 0,2 & 0,2 & 0,2 & 0,2 & 0,2 & 0,2 \\
\hline \multirow[t]{2}{*}{$\begin{array}{l}\text { Formative time } \\
\text { scale }\end{array}$} & $\begin{array}{l}\text { Time scale to empty } \\
\text { the basin until - } \\
2410 \mathrm{~m}\end{array}$ & months & 0,29 & 0,10 & 0,05 & 0,035 & 0,025 & 0,019 & 0,015 & 0,014 \\
\hline & $\begin{array}{l}\text { Time-scale to carve } \\
\text { the outlet } \\
\text { (suspension } \\
\text { dominated) }\end{array}$ & months & 436 & 60 & 19 & 8 & 4 & 3 & 2 & 1,5 \\
\hline
\end{tabular}


Accepted paper in Astrobiology - Vol. 8 (2020)

Time-scale to carve

months $202 \quad 93 \quad 60$

43

33,5

27,5

23

22 the outlet (bedload dominated)

\begin{tabular}{|c|c|c|c|c|c|c|c|c|c|c|}
\hline \multirow[t]{2}{*}{ Calculation } & \multirow[t]{2}{*}{ Parameters } & \multirow[t]{2}{*}{ Units } & \multicolumn{8}{|c|}{ Scenario Phase 2} \\
\hline & & & 1 & 2 & 3 & 4 & 5 & 6 & 7 & 8 \\
\hline \multirow[t]{3}{*}{ Input } & Channel width & $\mathrm{m}$ & 2500 & 2500 & 2500 & 2500 & 2500 & 2500 & 2500 & 2500 \\
\hline & Channel depth & $\mathrm{m}$ & 3 & 9 & 12 & 15 & 18 & 21 & 24 & 28 \\
\hline & Channel slope & $\mathrm{m} / \mathrm{m}$ & 0,028 & 0,037 & 0,040 & 0,043 & 0,045 & 0,047 & 0,049 & 0,051 \\
\hline Discharge & Friction factor & - & 0,28 & 0,36 & 0,39 & 0,42 & 0,44 & 0,45 & 0,47 & 0,49 \\
\hline \multirow[t]{3}{*}{ calculation } & Velocity & $\mathrm{m} / \mathrm{s}$ & 3,0 & 5,2 & 6,0 & 6,8 & 7,4 & 8,0 & 8,6 & 9,2 \\
\hline & Froude number & - & 0,9 & 0,9 & 0,9 & 0,9 & 0,9 & 0,9 & 0,9 & 0,9 \\
\hline & Discharge & km3/day & 2,0 & 10,1 & 15,6 & 21,9 & 28,8 & 36,3 & 44,3 & 55,8 \\
\hline \multirow{4}{*}{$\begin{array}{l}\text { Bedload } \\
\text { transport }\end{array}$} & Shields parameter & - & 0,09 & 0,17 & 0,21 & 0,24 & 0,27 & 0,30 & 0,33 & 0,37 \\
\hline & $\begin{array}{l}\text { Nondim. Transport } \\
\text { rate }\end{array}$ & - & 0,13 & 0,43 & 0,60 & 0,78 & 0,95 & 1,13 & 1,32 & 1,56 \\
\hline & $\begin{array}{l}\text { Volum. Transport } \\
\text { rate }\end{array}$ & $\mathrm{km}^{3} / \mathrm{day}$ & 0,0033 & 0,0113 & 0,0157 & 0,0203 & 0,0248 & 0,0295 & 0,0344 & 0,0408 \\
\hline & $\begin{array}{l}\text { Water/sediment } \\
\text { ratio }\end{array}$ & - & 597 & 896 & 998 & 1079 & 1159 & 1228 & 1288 & 1368 \\
\hline $\begin{array}{l}\text { Total load } \\
\text { transport }\end{array}$ & Shields parameter & - & 0,3 & 1,3 & 1,9 & 2,6 & 3,2 & 3,9 & 4,7 & 5,7 \\
\hline \multirow[t]{3}{*}{$\begin{array}{l}\text { Suspension } \\
\text { dominated }\end{array}$} & $\begin{array}{l}\text { Nondim. Transport } \\
\text { rate }\end{array}$ & - & 0,02 & 0,6 & 1,3 & 2,6 & 4,3 & 6,8 & 10,2 & 15,9 \\
\hline & $\begin{array}{l}\text { Volum. Transport } \\
\text { rate }\end{array}$ & $\mathrm{km}^{3} / \mathrm{day}$ & 0,004 & 0,032 & 0,102 & 0,232 & 0,449 & 0,752 & 1,173 & 1,391 \\
\hline & $\begin{array}{l}\text { Water/sediment } \\
\text { ratio }\end{array}$ & - & 3157 & 690 & 459 & 328 & 255 & 204 & 167 & 135 \\
\hline Erosion & $\begin{array}{l}\text { Sediment breach } \\
\text { volume }\end{array}$ & $\mathrm{km}^{3}$ & 3 & 3 & 3 & 3 & 3 & 3 & 3 & 3 \\
\hline Discharge & Inlet & $\mathrm{km}^{3} /$ day & 0,2 & 0,2 & 0,2 & 0,2 & 0,2 & 0,2 & 0,2 & 0,2 \\
\hline \multirow[t]{3}{*}{$\begin{array}{l}\text { Formative time } \\
\text { scale }\end{array}$} & $\begin{array}{l}\text { Time scale to empty } \\
\text { the basin until - } \\
2410 \mathrm{~m} \text { (pure water) }\end{array}$ & months & 0,8 & 0,1 & 0,09 & 0,07 & 0,05 & 0,04 & 0,03 & 0,02 \\
\hline & $\begin{array}{l}\text { Time-scale to carve } \\
\text { the outlet } \\
\text { (suspension } \\
\text { dominated) }\end{array}$ & months & 3071 & 129 & 56 & 28 & 17 & 11 & 7 & 4,5 \\
\hline & $\begin{array}{l}\text { Time-scale to carve } \\
\text { the outlet (bedload } \\
\text { dominated) }\end{array}$ & months & 581 & 168 & 121 & 94 & 77 & 64 & 55 & 47 \\
\hline
\end{tabular}

\begin{tabular}{|c|c|c|c|c|c|c|c|c|c|c|}
\hline \multirow[t]{2}{*}{ Calculation } & \multirow[t]{2}{*}{ Parameters } & \multirow[t]{2}{*}{ Units } & \multicolumn{8}{|c|}{ Scenario Phase 3} \\
\hline & & & 1 & 2 & 3 & 4 & 5 & 6 & 7 & 8 \\
\hline \multirow[t]{3}{*}{ Input } & Channel width & $m$ & 4000 & 4000 & 4000 & 4000 & 4000 & 4000 & 4000 & 4000 \\
\hline & Channel depth & $\mathrm{m}$ & 5 & 10 & 15 & 20 & 25 & 30 & 35 & 37 \\
\hline & Channel slope & $\mathrm{m} / \mathrm{m}$ & 0,032 & 0,038 & 0,043 & 0,046 & 0,05 & 0,053 & 0,055 & 0,057 \\
\hline Discharge & Friction factor & - & 0,31 & 0,37 & 0,42 & 0,45 & 0,48 & 0,51 & 0,52 & 0,54 \\
\hline \multirow[t]{3}{*}{ calculation } & Velocity & $\mathrm{m} / \mathrm{s}$ & 3,9 & 5,5 & 6,7 & 7,7 & 8,7 & 9,5 & 10,2 & 10,6 \\
\hline & Froude number & - & 0,9 & 0,9 & 0,9 & 0,9 & 0,9 & 0,9 & 0,9 & 0,9 \\
\hline & Discharge & $\mathrm{km}^{3} /$ day & 2,5 & 7,1 & 13,1 & 20,1 & 28,1 & 37,0 & 46,5 & 50,7 \\
\hline Bedload & Shields parameter & - & 0,12 & 0,18 & 0,24 & 0,29 & 0,34 & 0,38 & 0,42 & 0,44 \\
\hline
\end{tabular}

Salese et al., 2020b 
Accepted paper in Astrobiology - Vol. 8 (2020)

\begin{tabular}{|c|c|c|c|c|c|c|c|c|c|c|}
\hline & $\begin{array}{l}\text { Nondim. Transport } \\
\text { rate }\end{array}$ & - & 0,22 & 0,48 & 0,77 & 1,05 & 1,37 & 1,68 & 1,98 & 2,14 \\
\hline & $\begin{array}{l}\text { Volum. Transport } \\
\text { rate }\end{array}$ & $\mathrm{km}^{3} / \mathrm{day}$ & 0,0035 & 0,0076 & 0,0121 & 0,0165 & 0,0214 & 0,0263 & 0,0311 & 0,0335 \\
\hline & $\begin{array}{l}\text { Water/sediment } \\
\text { ratio }\end{array}$ & - & 718 & 936 & 1084 & 1219 & 1313 & 1404 & 1496 & 1514 \\
\hline $\begin{array}{l}\text { Total load } \\
\text { transport }\end{array}$ & Shields parameter & - & 0,6 & 1,5 & 2,6 & 3,7 & 5,0 & 6,4 & 7,7 & 8,4 \\
\hline \multirow[t]{3}{*}{$\begin{array}{l}\text { Suspension } \\
\text { dominated }\end{array}$} & $\begin{array}{l}\text { Nondim. Transport } \\
\text { rate }\end{array}$ & - & 0,1 & 0,8 & 2,6 & 5,8 & 11,6 & 20,2 & 31,3 & 38,4 \\
\hline & $\begin{array}{l}\text { Volum. Transport } \\
\text { rate }\end{array}$ & $\mathrm{km}^{3} / \mathrm{day}$ & 0,002 & 0,012 & 0,040 & 0,091 & 0,182 & 0,316 & 0,491 & 0,601 \\
\hline & $\begin{array}{l}\text { Water/sediment } \\
\text { ratio }\end{array}$ & - & 1544 & 594 & 326 & 220 & 154 & 117 & 95 & 84 \\
\hline Erosion & $\begin{array}{l}\text { Sediment breach } \\
\text { volume }\end{array}$ & $\mathrm{km}^{3}$ & 3 & 3 & 3 & 3 & 3 & 3 & 3 & 3 \\
\hline Discharge & Inlet & $\mathrm{km}^{3} / \mathrm{day}$ & 0,2 & 0,2 & 0,2 & 0,2 & 0,2 & 0,2 & 0,2 & 0,2 \\
\hline \multirow[t]{3}{*}{$\begin{array}{l}\text { Formative time } \\
\text { scale }\end{array}$} & $\begin{array}{l}\text { Time scale to empty } \\
\text { the basin until - } \\
2410 \mathrm{~m}\end{array}$ & months & 2 & 0,7 & 0,35 & 0,25 & 0,16 & 0,12 & 0,1 & 0,09 \\
\hline & $\begin{array}{l}\text { Time-scale to carve } \\
\text { the outlet } \\
\text { (suspension } \\
\text { dominated) }\end{array}$ & months & 1164 & 159 & 47 & 20 & 10 & 6 & 4 & 3 \\
\hline & $\begin{array}{l}\text { Time-scale to carve } \\
\text { the outlet (bedload } \\
\text { dominated) }\end{array}$ & months & 541 & 250 & 157 & 115 & 89 & 72 & 61 & 57 \\
\hline
\end{tabular}

\section{References}

Adami, L., W. Bertoldi, and G. Zolezzi (2016), Multidecadal dynamics of alternate bars in the Alpine Rhine River, Water Resources Research, 52(11), 8921-8938, doi:10.1002/2015wr018228.

Adeli, S., E. Hauber, M. Kleinhans, L. Le Deit, T. Platz, P. Fawdon, and R. Jaumann (2016), Amazonian-aged fluvial system and associated ice-related features in Terra Cimmeria, Mars, Icarus, 277, 286-299, doi:10.1016/j.icarus.2016.05.020.

Adler, J. B., J. F. Bell, P. Fawdon, J. Davis, N. H. Warner, E. Sefton-Nash, and T. N. Harrison (2018), Hypotheses for the Origin of the Hypanis Fan-Shaped Deposit at the Edge of the Chryse Escarpment, Mars: Is it a Delta?, Icarus.

Berendsen, H. J. A., and E. Stouthamer (2000), Late Weichselian and Holocene palaeogeography of the Rhine-Meuse delta, the Netherlands, Palaeogeography, Palaeoclimatology, Palaeoecology, 161(3-4), 311335.

Brakenridge, G. R., H. E. Newsom, and V. R. Baker (1985), Ancient Hot Springs on Mars - Origins and Paleoenvironmental Significance of Small Martian Valleys, Geology, 13(12), 859-862, doi:Doi 10.1130/00917613(1985)13<859:Ahsomo>2.0.Co;2.

Bretz, J. H. (1969), The Lake Missoula floods and the channeled scabland, The Journal of Geology, 77(5), 505-543. 
Accepted paper in Astrobiology - Vol. 8 (2020)

Brutsaert, W. (1982), The surface roughness parameterization, in Evaporation into the Atmosphere, edited, pp. 113-127, Springer.

Brutsaert, W., and M. B. Parlange (1998), Hydrologic cycle explains the evaporation paradox, Nature, 396(6706), 30-30, doi:Doi 10.1038/23845.

Coleman, N. M. (2013), Hydrographs of a Martian flood from a breached crater lake, with insights about flow calculations, channel erosion rates, and chasma growth, J Geophys Res-Planet, 118(2), 263-277, doi:10.1029/2012je004193.

Coleman, N. M. (2015), Hydrographs of a Martian flood from the breach of Galilaei Crater, Geomorphology, 236, 90-108, doi:10.1016/j.geomorph.2015.01.034.

Cratsley, D. W. (1975), Recent Deltaic Sedimentation, Atchafalaya Bay, Louisiana, Unpublished MS thesis, Louisiana State University, Baton Rouge, 142pp.

de Villiers, G., M. G. Kleinhans, and G. Postma (2013), Experimental delta formation in crater lakes and implications for interpretation of Martian deltas, Journal of Geophysical Research: Planets, 118(4), 651-670. Di Achille, G., and B. M. Hynek (2010), Ancient ocean on Mars supported by global distribution of deltas and valleys, Nature Geoscience, 3(7), 459.

Di Achille, G., G. G. Ori, and D. Reiss (2007), Evidence for late Hesperian lacustrine activity in Shalbatana Vallis, Mars, Journal of Geophysical Research E: Planets, 112(7), doi:10.1029/2006JE002858.

Di Achille, G., G. G. Ori, D. Reiss, E. Hauber, K. Gwinner, G. Michael, and G. Neukum (2006), A steep fan at Coprates Catena, Valles Marineris, Mars, as seen by HRSC data, Geophysical research letters, 33(7).

Duller, R. A., N. P. Mountney, A. J. Russell, and N. C. Cassidy (2008), Architectural analysis of a volcaniclastic jökulhlaup deposit, southern Iceland: sedimentary evidence for supercritical flow, Sedimentology, 55(4), 939-964, doi:10.1111/j.1365-3091.2007.00931.x.

Duller, R. A., N. H. Warner, S. De Angelis, J. J. Armitage, and M. Poyatos-More (2015), Reconstructing the timescale of a catastrophic fan-forming event on Earth using a Mars model, Geophysical Research Letters, 42(23), 10324-10332, doi:10.1002/2015gl066031.

Duller, R. A., N. H. Warner, C. McGonigle, S. De Angelis, A. J. Russell, and N. P. Mountney (2014), Landscape reaction, response, and recovery following the catastrophic 1918 Katla jökulhlaup, southern Iceland, Geophysical Research Letters, 41(12), 4214-4221, doi:10.1002/2014gl060090.

Edmonds, D. A., J. B. Shaw, and D. Mohrig (2011), Topset-dominated deltas: A new model for river delta stratigraphy, Geology, 39(12), 1175-1178, doi:10.1130/G32358.1.

Ehlmann, B. L., J. F. Mustard, C. I. Fassett, S. C. Schon, J. W. Head, D. J. D. Marais, J. A. Grant, and S. L. Murchie (2008), Clay minerals in delta deposits and organic preservation potential on Mars, Nature Geoscience, 1(6), 355-358, doi:10.1038/ngeo207.

Falcini, F., and D. J. Jerolmack (2010), A potential vorticity theory for the formation of elongate channels in river deltas and lakes, J Geophys Res-Earth, 115(F4), doi:Artn F04038

10.1029/2010jf001802.

Fassett, C. I., and T. A. Goudge (2017), Hydrological modeling of the Jezero crater outlet-forming flood.

Fassett, C. I., and J. W. Head (2005), Fluvial sedimentary deposits on Mars: Ancient deltas in a crater lake in the Nili Fossae region, Geophysical Research Letters, 32(14), doi:Artn L14201

$10.1029 / 2005 \mathrm{gl023456.}$

Gilbert, G. K. (1890), Lake Bonneville, US Government Printing Office.

Goudge, T. A., C. I. Fassett, and D. Mohrig (2018), Characterizing the record of paleolake outlet canyon incision on Mars paper presented at Lunar and Planetary Science Conference.

Goudge, T. A., J. F. Mustard, J. W. Head, C. I. Fassett, and S. M. Wiseman (2015), Assessing the mineralogy of the watershed and fan deposits of the Jezero crater paleolake system, Mars, J Geophys Res-Planet, 120(4), 775-808, doi:10.1002/2014je004782.

Salese et al., 2020b 
Accepted paper in Astrobiology - Vol. 8 (2020)

Halevy, I., and J. W. Head (2014), Episodic warming of early Mars by punctuated volcanism, Nature Geoscience, 7(12), 865-868, doi:10.1038/Ngeo2293.

Hauber, E., T. Platz, D. Reiss, L. Le Deit, M. G. Kleinhans, W. A. Marra, T. de Haas, and P. Carbonneau (2013), Asynchronous formation of Hesperian and Amazonian-aged deltas on Mars and implications for climate, Journal of Geophysical Research: Planets, 118(7), 1529-1544.

Hendriks, M. (2010), Introduction to physical hydrology, Oxford University Press.

Hill, P. R., C. P. Lewis, S. Desmarais, V. Kauppaymuthoo, and H. Rais (2001), The Mackenzie Delta:

Sedimentary processes and facies of a high-latitude, fine-grained delta, Sedimentology, 48(5), 1047-1078.

Hoke, M. R. T., B. M. Hynek, and G. E. Tucker (2011), Formation timescales of large Martian valley networks, Earth and Planetary Science Letters, 312(1-2), 1-12, doi:10.1016/j.epsl.2011.09.053.

Holo, S. J., and E. S. Kite (2017), Incision of the Jezero Crater Outflow Channel by Fluvial Sediment Transport, LPI Contributions, 2014.

Irwin III, R. P., A. D. Howard, R. A. Craddock, and J. M. Moore (2005), An intense terminal epoch of widespread fluvial activity on early Mars: 2. Increased runoff and paleolake development, Journal of Geophysical Research: Planets, 110(E12).

Irwin, R. P., A. D. Howard, and T. A. Maxwell (2004), Geomorphology of Ma'adim Vallis, Mars, and associated paleolake basins, J Geophys Res-Planet, 109(E12), doi:Artn E12009

10.1029/2004je002287.

Irwin, R. P., K. W. Lewis, A. D. Howard, and J. A. Grant (2015), Paleohydrology of Eberswalde crater, Mars, Geomorphology, 240, 83-101, doi:10.1016/j.geomorph.2014.10.012.

Kleinhans, M. G. (2005), Flow discharge and sediment transport models for estimating a minimum timescale of hydrological activity and channel and delta formation on Mars, J Geophys Res-Planet, 110(E12), doi:Artn E12003

10.1029/2005je002521.

Kleinhans, M. G., H. E. van de Kasteele, and E. Hauber (2010), Palaeoflow reconstruction from fan delta morphology on Mars, Earth and Planetary Science Letters, 294(3-4), 378-392,

doi:10.1016/j.epsl.2009.11.025.

Kohler, M. A., T. J. Nordenson, and W. E. Fox (1955), Evaporation from pans and lakes: US weather bureau research paper 38., US Weather Bureau, Washington, DC.

Kraal, E. R., M. van Dijk, G. Postma, and M. G. Kleinhans (2008), Martian stepped-delta formation by rapid water release, Nature, 451(7181), 973-976, doi:10.1038/nature06615.

Latimer, R. A., and C. W. Schweizer (1951), The Atchafalaya River Study: A Report Based Upon Engineering and Geological Studies of the Enlargement of Old and Atchafalaya Rivers., Mississippi River Commission.

Lowe, L. D., J. A. Webb, R. J. Nathan, T. Etchells, and H. M. Malano (2009), Evaporation from water supply reservoirs: An assessment of uncertainty, Journal of Hydrology, 376(1-2), 261-274,

doi:10.1016/j.jhydrol.2009.07.037.

Majersky, S., H. H. Roberts, R. Cunningham, G. P. Kemp, and C. J. John (1997), Facies development in the Wax Lake Outlet delta: Present and future trends, Basin Research Institute Bulletin, 7(1), 50-66.

Malin, M. C., et al. (2007), Context Camera Investigation on board the Mars Reconnaissance Orbiter, J Geophys Res-Planet, 112(E5), doi:Artn E05s04

10.1029/2006je002808.

Malin, M. C., and K. S. Edgett (2001), Mars Global Surveyor Mars Orbiter Camera: Interplanetary cruise through primary mission, J Geophys Res-Planet, 106(E10), 23429-23570, doi:10.1029/2000je001455.

Mangold, N., E. S. Kite, M. G. Kleinhans, H. Newsom, V. Ansan, E. Hauber, E. Kraal, C. Quantin, and K. Tanaka (2012), The origin and timing of fluvial activity at Eberswalde crater, Mars, Icarus, 220(2), 530-551, doi:10.1016/j.icarus.2012.05.026.

Salese et al., 2020b 
Accepted paper in Astrobiology - Vol. 8 (2020)

Marra, W. A., L. Braat, A. W. Baar, and M. G. Kleinhans (2014), Valley formation by groundwater seepage, pressurized groundwater outbursts and crater-lake overflow in flume experiments with implications for Mars, Icarus, 232, 97-117, doi:10.1016/j.icarus.2013.12.026.

McEwen, A. S., et al. (2007), Mars Reconnaissance Orbiter's High Resolution Imaging Science Experiment (HiRISE), J Geophys Res-Planet, 112(E5), doi:Artn E05s02

10.1029/2005je002605.

Moore, J. M., A. D. Howard, W. E. Dietrich, and P. M. Schenk (2003), Martian layered fluvial deposits: implications for Noachian climate scenarios, Geophysical Research Letters, 30(24), doi:Artn 2292 10.1029/2003gl019002.

Morgan, J. P., and P. B. Larimore (1957), Changes in the Louisiana shoreline, Transactions Gulf Coast Association, Geological Societies, v. 7, p. 303-310.

Morgan, J. P., J. R. Van Lopik, and L. G. Nichols (1953), Occurrence and development of mudflats along the western

Louisiana coastRep., Louisiana State University.

Muller, G. (1966), The new Rhine delta in Lake Constance, in Shirley, M.L., and Ragsdale, J.E., eds., Deltas in Their Geologic Framework: Houston, Texas, Houston Geological Society, 107-124.

Neukum, G., et al. (2004), Recent and episodic volcanic and glacial activity on Mars revealed by the High Resolution Stereo Camera, Nature, 432(7020), 971-979, doi:10.1038/nature03231.

O'Connor, J. E., and V. R. Baker (1992), Magnitudes and implications of peak discharges from glacial Lake Missoula, Geological Society of America Bulletin, 104(3), 267-279.

O'Connor, J. E., and R. A. Beebee (2009), Floods from natural rock-material dams, Megaflooding on Earth and Mars, 128-163.

Ori, G. G., L. Marinangeli, and A. Baliva (2000), Terraces and Gilbert-type deltas in crater lakes in Ismenius Lacus and Memnonia (Mars), Journal of Geophysical Research: Planets, 105(E7), 17629-17641.

Parker, G., P. R. Wilcock, C. Paola, W. E. Dietrich, and J. Pitlick (2007), Physical basis for quasi-universal relations describing bankfull hydraulic geometry of single-thread gravel bed rivers, Journal of Geophysical Research: Earth Surface, 112(F4).

Pondrelli, M., A. P. Rossi, L. Marinangeli, E. Hauber, K. Gwinner, A. Baliva, and S. Di Lorenzo (2008), Evolution and depositional environments of the Eberswalde fan delta, Mars, Icarus, 197(2), 429-451, doi:10.1016/j.icarus.2008.05.018.

Roberts, H. H., R. D. Adams, and R. H. W. Cunningham (1980), Evolution of Sand-Dominant Subaerial Phase, Atchafalaya Delta, Louisiana, Aapg Bull, 64(2), 264-279.

Roberts, H. H., J. M. Coleman, S. J. Bentley, and N. Walker (2003), An embryonic major delta lobe: A new generation of delta studies in the Atchafalaya-Wax Lake Delta system.

Roberts, H. H., N. Walker, R. Cunningham, G. P. Kemp, and S. Majersky (1997), Evolution of sedimentary architecture and surface morphology: Atchafalaya and Wax Lake Deltas, Louisiana (1973-1994).

Roda, M., M. G. Kleinhans, T. E. Zegers, and J. H. P. Oosthoek (2014), Catastrophic ice lake collapse in Aram Chaos, Mars, Icarus, 236, 104-121, doi:10.1016/j.icarus.2014.03.023.

Salese, F., G. Di Achille, A. Neesemann, G. G. Ori, and E. Hauber (2016), Hydrological and sedimentary analyses of well-preserved paleofluvial-paleolacustrine systems at Moa Valles, Mars, Journal of Geophysical Research: Planets, 121(2), 194-232.

Salese, F., M. Pondrelli, A. Neeseman, G. Schmidt, and G. G. Ori (2019), Geological evidence of planet-wide groundwater system on Mars, Journal of Geophysical Research: Planets, doi:10.1029/2018JE005802.

Schon, S. C., J. W. Head, and C. I. Fassett (2012), An overfilled lacustrine system and progradational delta in Jezero crater, Mars: Implications for Noachian climate, Planetary and Space Science, 67(1), 28-45, doi:10.1016/j.pss.2012.02.003. 
Accepted paper in Astrobiology - Vol. 8 (2020)

Sears, D. W. G., and J. D. Chittenden (2005), On laboratory simulation and the temperature dependence of the evaporation rate of brine on Mars, Geophysical Research Letters, 32(23), doi:Artn L23203 $10.1029 / 2005 \mathrm{gl024154.}$

Sears, D. W. G., and S. R. Moore (2005), On laboratory simulation and the evaporation rate of water on Mars, Geophysical Research Letters, 32(16), doi:Artn L16202

10.1029/2005gl023443.

Shaw, J. B., F. Ayoub, C. E. Jones, M. P. Lamb, B. Holt, R. W. Wagner, T. S. Coffey, J. A. Chadwick, and D.

Mohrig (2016), Airborne radar imaging of subaqueous channel evolution in Wax Lake Delta, Louisiana, USA, Geophysical Research Letters, 43(10), 5035-5042, doi:10.1002/2016gl068770.

Shaw, J. B., and D. Mohrig (2014), The importance of erosion in distributary channel network growth, Wax Lake Delta, Louisiana, USA, Geology, 42(1), 31-34, doi:10.1130/G34751.1.

Shlemon, R. J. (1975), Subaqueous delta formation-Atchafalaya Bay, Louisiana.

Shuttleworth, J. W. (1992), Evaporation, in Handbook of Hydrology, edited by D.R. Maidment, pp. 4.1-4.53, McGraw-Hill, New York.

Sklar, L. S., and W. E. Dietrich (2004), A mechanistic model for river incision into bedrock by saltating bed load, Water Resources Research, 40(6), doi:Artn W06301 10.1029/2003wr002496.

Syvitski, J. P. M. (2005), The morphodynamics of deltas and their distributary channels, in River, Coastal and Estuarine Morphodynamics, edited, pp. 146-153, CRC Press.

Tockner, K., U. Uehlinger, and C. T. Robinson (2009), Rivers of Europe, Academic Press.

Wallace, D., and C. Sagan (1979), Evaporation of Ice in Planetary-Atmospheres - Ice-Covered Rivers on Mars, Icarus, 39(3), 385-400, doi:Doi 10.1016/0019-1035(79)90148-9.

Weitz, C. M., R. P. Irwin, F. C. Chuang, M. C. Bourke, and D. A. Crown (2006), Formation of a terraced fan deposit in Coprates Catena, Mars, Icarus, 184(2), 436-451, doi:10.1016/j.icarus.2006.05.024.

Wellner, R., R. Beaubouef, J. Van Wagoner, H. H. Roberts, and T. Sun (2005), Jet-plume depositional bodies - the primary building blocks of Wax Lake Delta.

Wells, J., S. Chinburg, and J. M. Coleman (1982), Development of the Atchafalaya River deltas: generic analysis. , U.S. Army Corps of Engineers, waterways Experiment Station, Vicksburg, MS, $96 p$.

Wessels, M., F. Anselmetti, R. Artuso, R. Baran, G. Daut, S. Gaide, A. Geiger, J. D. Groeneveld, M. Hilbe, and K. Möst (2015a), Bathymetry of Lake Constance-a High-Resolution Survey in a Large, Deep Lake, Zeitschrift für Geodäsie, Geoinformation und Landmanagement, 140(4), 203-210.

Wessels, M., F. Anselmetti, R. Artuso, R. Baran, G. Daut, A. Geiger, S. Gessler, M. Hilbe, K. Möst, and B. Klauser (2015b), Bathymetry of Lake Constance-State-of-the-art in surveying a large lake, Hydrographischen Nachrichten, 2, 6-11.

Wessels, M., F. Anselmetti, R. Baran, M. Hilbe, S. Gessler, and P. Wintersteller (2016), TiefenschärfeHochauflösende Vermessung Bodensee, Internationale Gewässerschutzkommission für den Bodensee (IGKB).

Williams, R. M. E., et al. (2013), Martian Fluvial Conglomerates at Gale Crater, Science, 340(6136), 10681072, doi:10.1126/science.1237317. 